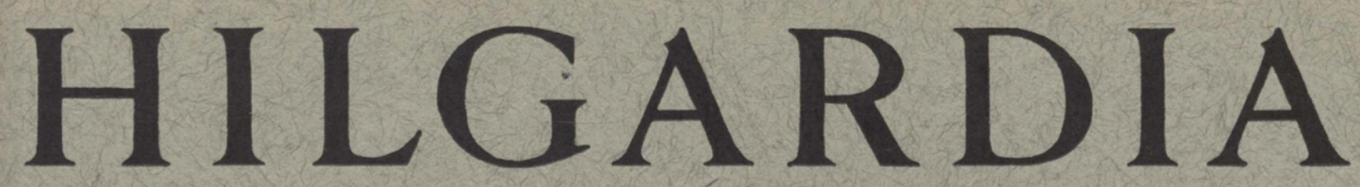

A Journal of Agricultural Science Published by the California Agricultural Experiment Station

\title{
A PHYSIOLOGICAL STUDY OF BORON DEFICIENCY IN PLANTS
}

HOWARD S. REED 


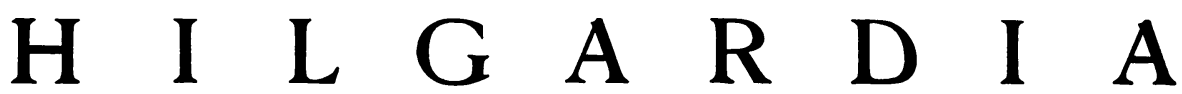

A Journal of Agricultural Science Published by

the California Agricultural Experiment Station

VoL. 17

MAY, 1947

No. 11

\section{A PHYSIOLOGICAL STUDY OF BORON DEFICIENCY IN PLANTS ${ }^{1}$}

\author{
HOWARD S. REED ${ }^{2}$
}

\section{INTRODUCTION}

Problems relating to the nutrition of plants have assumed an increasing importance since it is now evident that the so-called micronutrients play an important role not only in the physiology of the plants but often of animals which feed upon them. True, most soils contain these elements, but soils are known in which the amounts necessary for healthy plant growth fall below the critical level.

It is a matter of record that the systems of farming in California which expanded horticulture in the latter part of the nineteenth and early twentieth centuries were for a time highly successful, but eventually in certain districts the fruit and vegetable crops were affected with hitherto unknown maladies unrelated to attacks of plant-disease organisms or of insects. The new maladies were termed "dieback," "yellow leaf," "sour sap," "little-leaf," "mottle-leaf," "cork spot," "decline," and others, all of which connoted a general lack of vitality and fruitfulness. In an attempt to remedy the condition, soil amendments which included a wide range of materials were applied to orchards and fields, sometimes with success, but often contrariwise. When conventional methods of treatment failed to ameliorate the situation, it became apparent that new studies must be undertaken to ascertain the underlying causes of the unexplained crop failures.

The problems were investigated from various angles; often false starts were made, but eventually it was discovered that small amounts of the micronutrients could overcome the unthrifty condition of some of the trees. An extensive series of experiments has demonstrated that the application of small quantities of manganese, or iron, or boron, or zinc can often restore unhealthy plants to vigor. Usually the salts of these elements are applied directly to the tree, but in vegetable growing they are applied to the soil.

Many of the problems connected with this phase of plant nutrition are still unsolved. Additional investigations are therefore essential to obtain accurate

\footnotetext{
${ }^{1}$ Received for publication August 27, 1946.

${ }^{2}$ Professor of Plant Physiology and Plant Physiologist in the Experiment Station, Emeritus.
} 
information about the underlying causes of the abnormal behavior of plants whose nutrition is deficient in one or another micronutrient. But haphazard treatments and empirical methods have been displaced by scientific researches. There is no substitute for accurate information derived from controlled observations and controlled experiments.

The apparent lack of micronutrients in the soils in many parts of the world emphasizes the broad scope of the problems. Space forbids the briefest mention of the studies made by many workers on many plants in many lands which year by year have added to the store of information on the subject. The economic and scientific importance of the problem justifies researches on the effects of these hitherto unappreciated factors in plant growth.

The present paper deals with the effects of boron deficiency in the olive, celery, and sunflower, with brief consideration of some other plants. Clinical symptoms of the affected plants are described as well as possible to facilitate the diagnosis of the maladies ensuing from an inadequate boron supply or from adverse conditions which impair the power of the soil to furnish boron. The derangements in the conducting systems of the plants, as well as in the centers of synthesis of substances necessary for growth, are considered. Especial attention is devoted to cytochemical features of the leaf, of the primary meristem, of the phloem elements, and of other cellular structures.

The author expresses his gratitude to many colleagues for their helpful suggestions and criticisms during the course of the investigation.

\section{OLIVE}

Boron deficiency in the olive tree has been recently described by Scott, Thomas, and Thomas (1943), ${ }^{8}$ who have studied the effects in bearing and young trees and have found that the symptoms are readily identifiable. During fall and winter some of the leaves of the current season's growth became pale green in the apical portions, whereas the basal part of the laminae retained the normal green color. Some leaves which had been chlorotic for several months developed bands of necrotic tissue in the distal regions. Affected trees, owing to the death of terminal buds and subsequent secondary growth from lateral buds, had a bushy appearance. In severe cases these secondary shoots may die in the same season. Branches often died at the end of the growing season, although they had shown good growth and very mild symptoms a short time previously. Haas (1945) reported data on the chemical aspects of the nutrition of the olivè, especially on the translocation of boric salts into the leaves.

The first-mentioned investigators kindly placed at my disposal much of the material used in the present study. Small trees grown in soil deficient in its boron-supplying power produced dwarfed shoots and leaves (fig. 1) unless boric acid was added to the soil. Characteristically the terminal bud on the main shoot of the young tree died at the end of the first season's growth. Subsequent shoot growth developed from upper lateral buds, giving the tree a $Y$ shape, or from basal buds which had been previously inhibited by the dominance of the main axis.

${ }^{s}$ See "Literature Cited" for complete data on citations, which are referred to in the text by author and date of publication. 


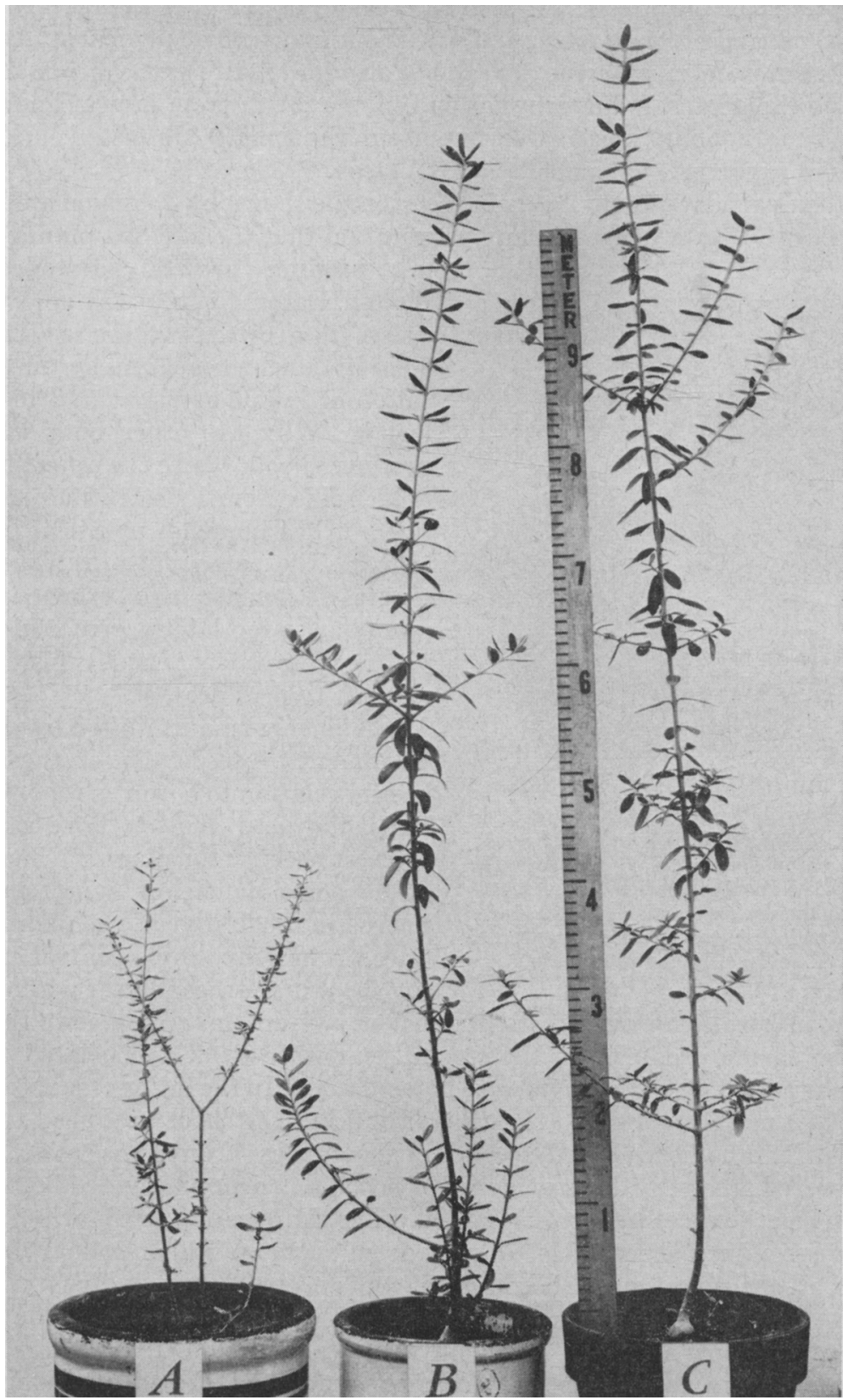

Fig. 1.-Olive trees grown in soil which was known to have a low boronsupplying power. Jar $A$, no boron added; $B, 0.5$ gram boron added; $C, 0.12$ gram boron added. (Photographed May 18, 1945, by courtesy of the Division of Plant Pathology.) 
The growth of the apical meristem and the development of the various rudiments which arise from it command attention in any physiological study. Not only is boron necessary for the growth but also for the life of the terminal bud; yet, after the death of the terminal bud, new growth from lateral buds goes on for a time, not only in the olive, but also in the tomato (Johnston and Dore, 1929) and sugar beet (Brenchley and Watson, 1937).

The development of new shoots in the example shown by Johnston and Dore and in figure 1, speaks against any assumption that the affected plants could

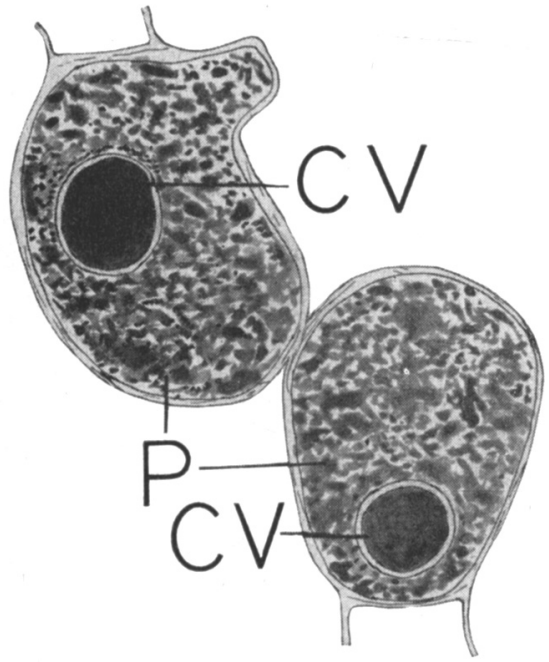

Fig. 2.--Mesophyll cells in an olive leaf showing boron deficiency. $C V$, coacervates of pyridoxin enveloped with lipoid material; $P$, phenolic material which filled the vacuoles and obscured other cell contents. Sudan III and methylene blue stain. not produce growth hormones, although Eaton (1940) was able to increase the growth of cotton seedlings in a boron-deficient medium by the application of indole acetic acid. The problem is: Why are other buds able to produce shoots where the apical bud is not? Aside from its scientific implications, it has immense practical importance. The surviving replacement shoots of tomato and other annual plants arise too late to give fruit, and young trees form a bushy instead of upright type of growth.

The phenomena exhibited by the development of seedstalks of the sugar beet in relation to boron as reported by Brenchley and Watson have especial interest because the plant is a biennial. If no boron-deficiency symptoms appeared in the first year, the plants produced a healthy single central flowering shoot in the second year without the addition of boron; however, if slight deficiency symptoms appeared in the first year, the shoots produced in the second year were weak and belated unless boron was added when the roots were transplanted. In the latter case the initial injury had not always killed the central bud but the shoot produced from it was weak. If it had been killed, secondary shoots arose around the crown, grew, and flowered freely, without evidence of boron deficiency provided boron was added when the roots were transplanted. Thus the question again arises : Why are the secondary shoots able to grow from roots on which primary shoots showed all the symptoms of boron deficiency and prematurely died?

Growth of the central flowering shoot of the carrot also fails if the boron supply falls below a certain threshold value (Warington, 1940). Necrosis of tissues begins in the region of the growing point of the shoot, though the meristematic apex is not necessarily the first to be involved. The components of the fibrovascular bundles are seriously affected by a lack of boron. On a subsequent page of this paper certain details of the histology and cytology of affected celery plants are presented, and further discussion of the question of the primary meristem will therefore be deferred. 
In the present study both cytological and cytochemical investigations were made of boron-deficient olive leaves.

Sections of both fresh and fixed material of healthy leaves, tested with the proper reagents, showed normal structure wherein the cells were free from phenolic and lipoidic substances. On the other hand, an examination of sections of dwarfed, chlorotic olive leaves borne on boron-deficient trees revealed that the cells of palisade parenchyma and mesophyll were replete with flocculent phenolic material which obscured everything except coacervates (fig. 2). When sections were stained with a combination of Sudan III and methylene blue, the enveloping layer of phospholipoid of the coacervate was stained deep pink. Supplementary tests showed that the central mass of the coacervates contained pyridoxine.

When stained with molybdenic acid reagent the surface layer was colored deep blue as a result of its interaction with phospholipoid. This reagent was prepared by the following formula:

Dissolve 6.41 grams of ammonium molybdate in 250 ce of $3 N$ sulfuric acid. This constitutes solution A. Dissolve 5.75 grams of sodium bisulfite in 85 ce distilled water. Add 5 grams of 1-amino 2-naphthol 4-sulfonic acid and 5 ec of a 20 per cent sodium sulfite solution. Stir the mixture until the sulfonic acid is dissolved. This constitutes solution $\mathrm{B}$. At the time of using, mix 25 ec of solution A and 5 ec of solution B.

The formation of phenolic aggregates in cells like those here studied is essentially a separation of phases in a physical sense as a result of impaired metabolism in cells affected by pathogens, by viruses, or by the deficiency of an essential element. In healthy cells the dihydroxyphenols (chiefly catechol) are uniformly dispersed in the vacuolar sap, which under the microscope appears optically empty. At pH 5, which approximates that of most vacuolar solutions, half the catechol present is in the oxidized and half in the reduced condition. It is not irreversibly oxidized because there is an equilibrium between the hydrogenases and the dehydrogenases. When the equilibrium is destroyed (by malnutrition, disease, or poisons), the catechol is oxidized to quinones, which may undergo rapid polymerization to more complex compounds. These, being but slightly soluble in the vacuolar sap, appear as flocculent material in various stages of aggregation in the vacuoles. (Reed, 1941). Even though the flocculent material becomes aggregated into globular precipitates (fig. 3 , bundle-sheath cells) or into coacervates, the cell may retain its vitality for a time, although the vacuolar solution is impoverished. Both kinds of aggregates may be formed if there is not enough phospholipoid or other desolvant, like lecithin, to form autocomplexes of all the polymerized phenolic material.

The phenolic compounds, as they lose hydrogen, develop ability for carbon linkages ; and the hydrogen enters into the formation of water, and the amount available to redisperse the polymerized phenolic compounds is thereby reduced (Mason, Schwartz, and Peterson, 1945). Everything indicates that the hydrogenase systems in these cells, which could have made hydrogen available, failed to act either because certain phosphorus linkages had been broken or because active - $\mathrm{SH}$ groups had been oxidized to disulfides (Reed and Dufrénoy, 1935). The survival of the cell depends upon several factors, such as respiration, illumination, transpiration, and specific characters of the plant. 
Certain aspects of respiration may appropriately be discussed here in relation to the physiological equilibriums of plant cells such as those of the olive leaf. In aerobic cells "compensated respiration" depends on the presence of active - $\mathrm{SH}$ groups able to release hydrogen as needed to rehydrogenate the dehydrogenated polyphenols or the dehydrogenated dienols. The energy which is liberated in these processes can be utilized by the cell. Compensated respiration therefore depends on the maintenance of the $\mathrm{rH}$ potential where cysteine may be in equilibrium with cystine as

$$
2 \mathrm{R}-\mathrm{SH} \rightleftarrows \mathrm{R}-\mathrm{S}-\mathrm{S}-\mathrm{R}+2 \mathrm{H}^{+}
$$

This is generally insured through the presence of glutathione, where the - $\mathrm{SH}$ group is stabilized through the polypeptide linkage of the molecule, so that the molecule acts as a reservoir of hydrogen, able to release hydrogen to cystine, which is thereby reduced to cysteine.

Active - SH groups are not likely to exist in the cell in high concentrations, as they are apt to link up with the aldehydic groups of tissue constituents either through a straight $-\mathrm{CHO}+-\mathrm{SH}$ linkage, or in the case of cysteine through the formation of a thiazoline or of a thiazolidine ring.

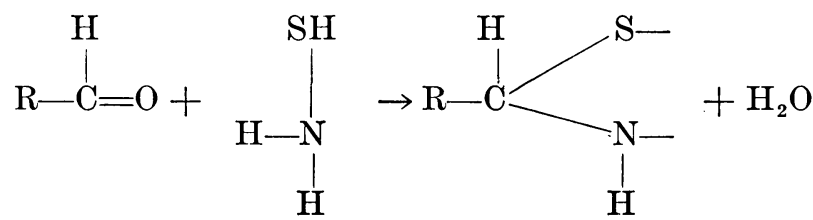

Such rings seem to play an important role in nucleoproteins, and denaturation involves the opening of the ring, with liberation of - $\mathrm{SH}$ groups, apt to oxidize into - S-S- groups.

When the respiration is "noncompensated" the dihydroxyphenols and other constituents of the cell are subject to further oxidations, resulting in changes of their physical condition (Humphrey and Dufrénoy, 1944).

Returning to the cytological features of the olive leaf, it is important to note that the fibrovascular system showed profound injury where boron was deficient. Eventually the phloem was destroyed. In the earlier stages the phenolic complex in the outer cells showed changes similar to those already described in the palisade and mesophyll tissues. There was first formed a mass of floceulent material in the cells of the bundle sheath. Normally this is an active metabolic system, in which materials are exchanged between the conducting vessels and the centers wherein complex products are manufactured by synthesis of incoming material. The condition shown in figure 3 indicates highly significant early stages in the process of vascular disintegration. The section was stained with acid fuchsin and methyl green. This brought out the fact that various cells were replete with one form or another of oxidized phenolic material. Sections of healthy olive leaves showed none of these alterations; their bundle-sheath cells contained starch. Sieve tubes and companion cells showed premature vacuolization and disruption of their contents. Later the phloem vessels were filled with dense melanotic material which stained deeply with haematoxylin or molybdenic acid reagent (figs. 4 and 5). As conduits for the 
translocation of solutes, their efficiency was almost completely destroyed. Characteristically in this stage of the process the black necrotic substance did not diffuse into adjacent cells. Its viscosity must be high.

A brief discussion of the origin of the melanotic substance is in order since it is such a constant characteristic of the phloem of boron-deficient plants. Nelson and Dawson (1944) showed how the enzymatic oxidation of catechol

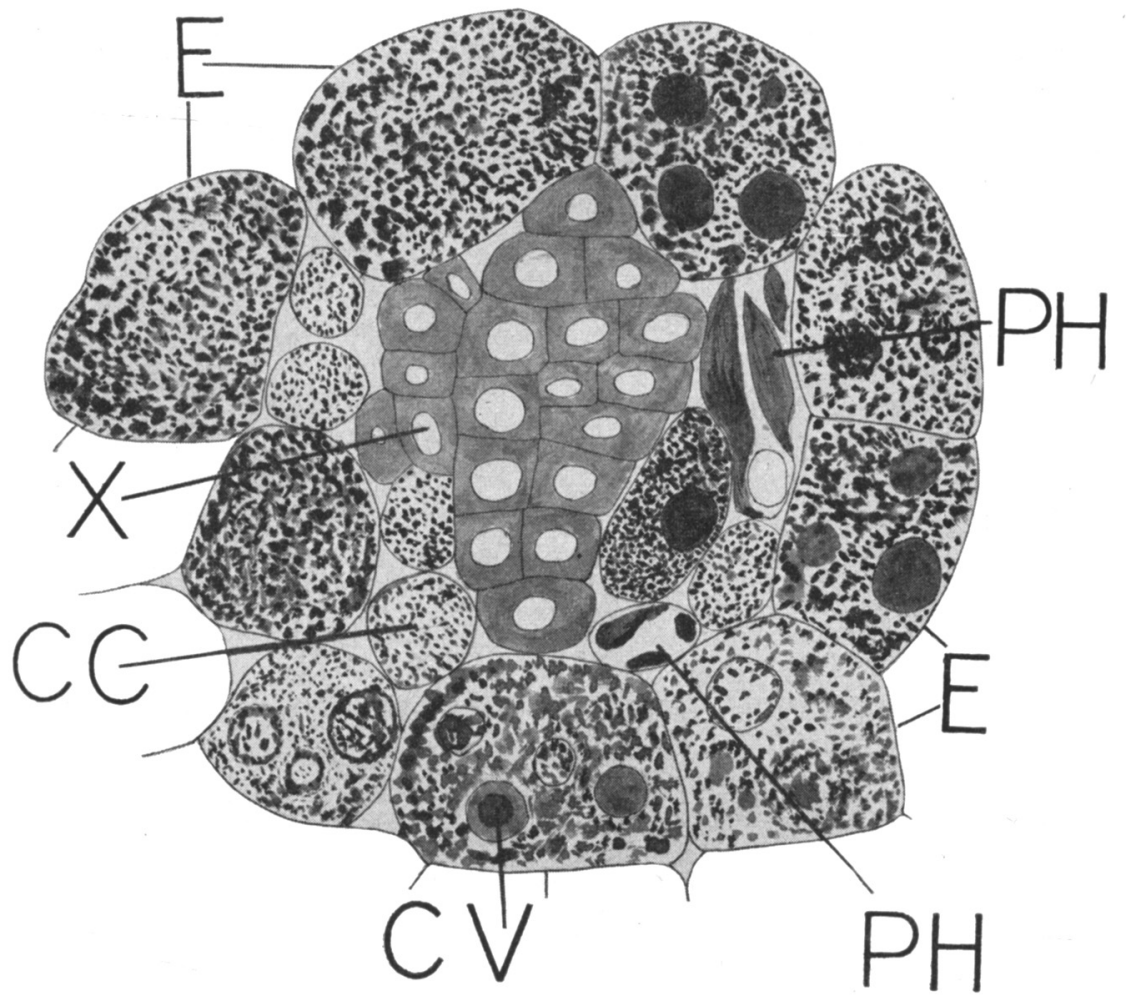

Fig. 3.-A fibrovascular bundle of an olive leaf showing boron deficiency. Derangements of phloem and bundle-sheath cells were evident. $C C$, companion cell; $C V$, coacervate; $E$, bundle-sheath containing phenolic material in various stages of aggregation; $P H$, phloem cells, seriously disorganized; $X$, xylem. Acid fuchsin and methyl green stain.

to 0 -benzoquinone can be followed (rapidly at $\mathrm{pH} 7$, slowly at $\mathrm{pH} 4$ ) by hydration of the oxidation product to hydroquinone to hydroxyquinone, which can rapidly polymerize to melanotic compounds. The proposed chain of reactions can be confirmed by measurements of the oxygen uptake and explains why a change in the rate of oxidation occurs at the one-atom stage, when very dilute solutions of catechol are enzymatically oxidized at relatively low $\mathrm{pH}$. The uptake of the second atom of oxygen is conditioned by the hydration of the $o$-benzoquinone.

All evidence concurs in showing that the phenol oxidase which catalyzes the first stages in this process is a copper-containing compound and that it is highly specific for the oxidation of $o$-dihydroxy-phenols such as catechol and 


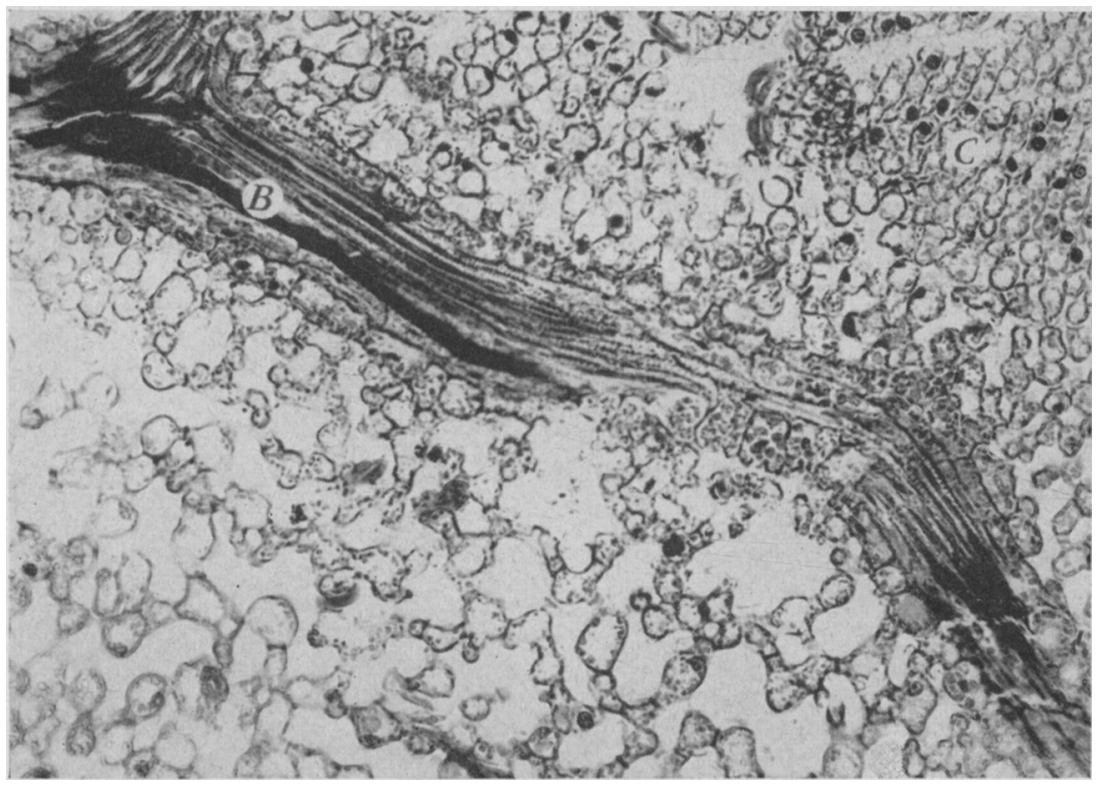

Fig. 4.-Part of a section of an olive leaf which was chlorotic as a result of boron deficiency, showing $(B)$ collapse of phloem and $(C)$ coacervates in the upper righthand corner. $(\times 600$.$) Molybdenic acid reagent and haematoxylin stain.$

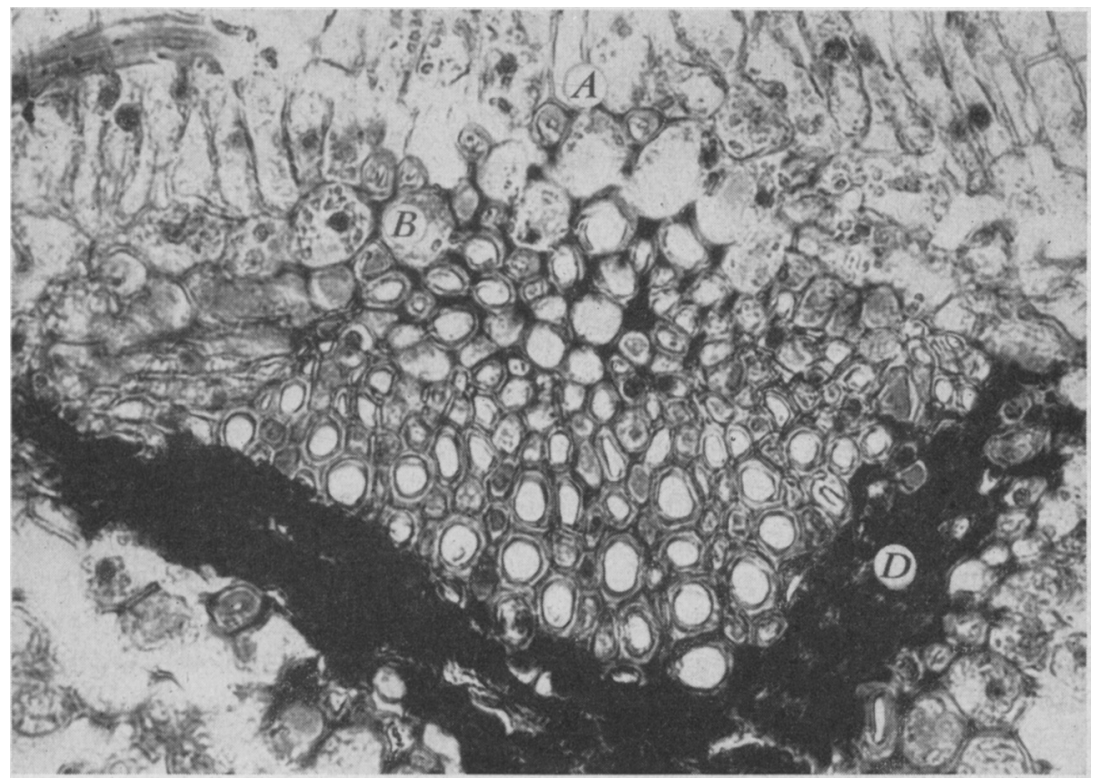

Fig. 5.-Part of a section of an olive leaf which was chlorotic as a result of boron deficiency, showing collapse of phloe̊m: $A$, palisade parenchyma; $B$, endodermal layer; $D$, necrotic phloem tissue. $(\times 600$.) Stained with molybdenic acid reagent and haematoxylin. (Material collected by Professor H. E. Thomas, Jan. 26, 1944.) 
pyrogallol. There is no convincing evidence that hydrogen peroxide is formed during the reactions which lead to the formation of the melanotic substance.

Mason, Schwartz, and Peterson (1945) presented spectrophotometric data on the mechanism of the enzymatic oxidation of catechols, whereby it seems probable that $o$-benzoquinone, the initial product of the oxidation, participates in a polymerization to a phenolic chain susceptible to further enzymatic oxidation. Kinetic spectrophotometry of the autoxidation, oxidation in the presence of unsaturated fatty esters, and oxidation in the presence of tyrosinase of 3 -n-pentadecylcatechol similarly lead to the conclusion that $3-n$-pentadecyl$o$-benzoquinone is the initial oxidation product in each case.

To summarize : boron deficiency in the olive results in : (1) the production of growth-inhibiting factors; (2) necrosis of the terminal bud and often of the distal part of the leaf; (3) the production of substances inimical to plastids and consequently limiting carbohydrate production; (4) impoverishment of the vacuolar solution, especially in the leaves; (5) disruption of fibrovascular system through increased oxidative activity, which produces excessive amounts of viscous melanotic substances from quinoids and other compounds flowing through the system; and (6) the production of some lethal material-probably quinoid, but as yet unidentified.

The cytophysiological study reveals that normally the phloem and bundle sheath are metabolic centers as well as conduits for the flow of material. The evidence gained affirms their importance in synthesizing and translocating energy-rich substances, among which energy-rich phosphorus compounds are definable. When phospholipoids are bound to the surface of coacervates, the vacuolar sap is necessarily impoverished in usable phosphorus.

The exact role of boron in maintaining the proper equilibrium in the plant cannot now be definitely stated. There is ample evidence that a small amount is essential for some exceedingly vital cellular processes and that it plays a primary role in the chemistry of the vacuolar solution. In boron-deficient plants the hydrogenase system of the cell fails, owing either to the blocking of the catalyst or to the lack of hydrogen donors, or both.

No valid arguments can be presented for the assumption that boron activity is intimately linked to the functions of cations essential in plant nutrition, though it is known that none of them has completely independent effects in a living system.

Further light on some of these matters will be obtained from data in the next part of this paper.

\section{CELERY}

It has been known for some time that cracked veins and hollow petioles are symptoms of boron deficiency in celery (Purvis and Ruprecht, 1937). The present experiments and observations on celery were designed to supplement, and confirm if possible, data on the olive leaf.

In many experiments with celery plants grown in nutrient solutions of highly purified salts, very definite symptoms of boron deficiency were repeatedly obtained. The leaf petioles grew slowly and eventually showed split veins and drying of the central pith, the leaflets were dwarfed, chlorotic, and eventually died at the margins, the roots grew slowly for a time but suffered 
for lack of organic nutrients from the tops. (Formerly such symptoms could be seen in market celery from certain districts but now, having learned the cause of the difficulty, the growers apply sufficient boron to eliminate the defects formerly seen.) In experiments where no boron was supplied to the nutrient medium, the bud at the apex of the shoot died, whereupon lateral accessory buds put out and made a little growth before the entire plant perished. When 0.05 p.p.m. of boron was supplied, the plants grew well for a time, but sooner or later showed chlorosis, split veins, and failed in other ways to develop into normal plants. Under the experimental conditions, 0.5 p.p.m. of boron was sufficient to produce strictly normal plants.

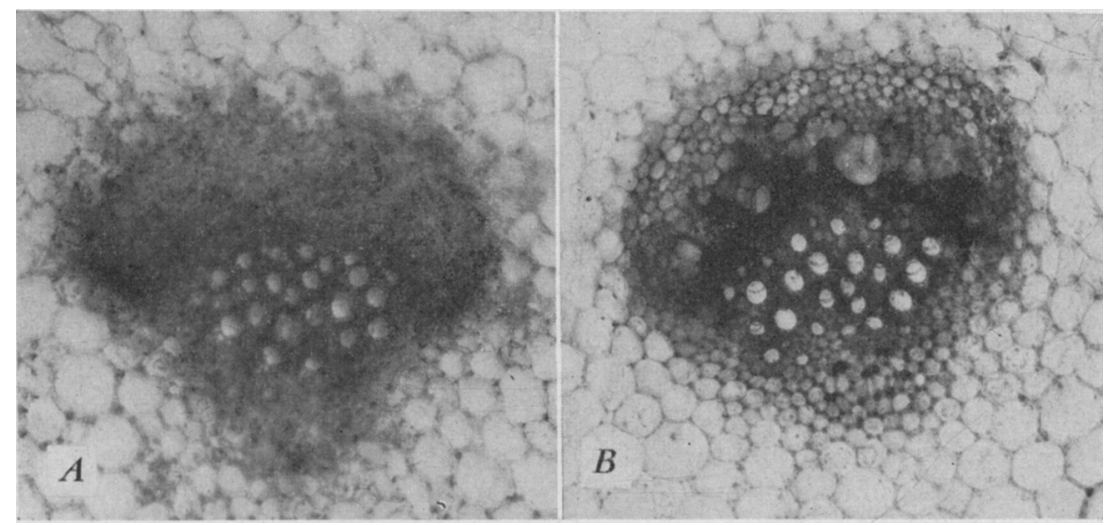

Fig. 6.-Fibrovascular bundles of celery. Free-hand sections after treatment with Gomori reagents: $A$, from healthy plant; $B$, from a boron-deficient plant in which the necrotic phloem contained inorganic phosphates.

Material from plants grown in solutions of highly purified salts was taken to the laboratory for cytological study. Thin sections of the petioles were tested for phosphates by the Gomori and by the molybdenic acid reagent. The cells of the parenchyma and xylem of boron-deficient plants were normal so far as structure and organization were concerned; but the necrotic phloem of boron-deficient petioles had become an unorganized mass of melanotic material in which inorganic phosphate had been trapped (fig. $6, B$ ). The intact oil ducts in the metaphloem were similar in all respects to those described by Esau (1936). The dyes which were applied to the fresh sections were more readily absorbed by the injured phloem than by other tissues of the borondeficient plants, probably on account of greater permeability of the former. Thionine and methylene blue were absorbed and stained the walls of collenchyma and bundle caps, but neither showed marked reduction.

The phloem in boron-deficient petioles was stained purplish pink by phosphomolybdate haematoxylin and brownish purple by phosphotungstic haematoxylin. The former dye also gave the typical blue of the phosphate ion when applied to sections of the boron-deficient petioles.

The parenchyma cells of both lots of celery plants reduced methylene blue, the reduction being somewhat more complete in the boron-deficient petiole sections. The parenchyma cells of healthy and affected petioles reacted some- 
what differently to brilliant cresyl blue dissolved in a solution buffered at $\mathrm{pH}$ 7. The reduction of the dye was more complete in the healthy petioles. The bundle cap next the fibrovascular bundle was very light blue in contrast to the darker blue of the phloem, which did not reduce the dye.

Additional evidence on the oxidoreducing substances was obtained from tests for phenol oxidase. Boron-deficient sections placed in thydi reagent ${ }^{4}$ showed a strong indophenol-blue reaction. Healthy sections, on the contrary, showed none; this difference indicates a stronger oxidase in the affected plants. Sections of affected plants absorbed neutral-red solution much more rapidly and completely than sections of healthy plants.

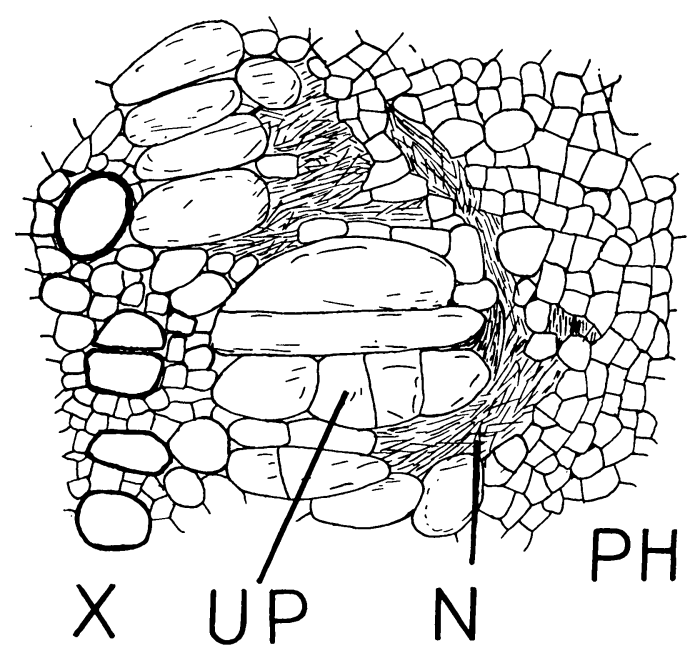

Fig. 7.-Fibrovascular bundle of a celery plant affected by boron deficiency: $P H$, phloem; $N$, early stage of necrosis in the phloem; $U P$, undifferentiated parenchyma; $X$, xylem.

Hypertrophy of parenchyma of affected petioles was commonly observed. The cambial cells were initially elongated in the radial direction and soon divided by transverse walls, but retained the character of parenchyma tissue. Figure 7 represents an early stage before serious derangements had occurred. The development of this undifferentiated parenchyma is responsible for the enlarged vascular strands which are characteristic of boron-deficient celery. It is generally obscured after extensive necrosis of the phloem has produced extruded melanotic material. Eltinge (1936) demonstrated in $Z e a$ affected by boron deficiency the hypertrophy of parenchyma cells, as well as collapse of mesophyll cells and subsequent necrosis.

4he formula is:

Solution A: Dissolve 0.5 gram thymol in 100 ce water (+ 0.5 ce conc. or strong $\mathrm{KOH}$ ) on steam bath. This will keep 15 days.

Solution B: Dissolve 0.5 gram $p$-dimethyl-phenylene-diamine-hydrochloride (or $p$-aminodimethyl-aniline) in 100 ce water. Add a few drops of $\mathrm{KOH}$ until rose color disappears, but not. enough to turn it blue.

For use: Add a few drops each of A and B to 20 ec water. A blue color should develop. The dye is not permanent and must be made up as used. 
Relevant information on this subject was obtained from studies on tomato leaves grown with inadequate supplies of boron. Cells of the palisade parenchyma were two to three times as long as normal, so that the leaflets became thick and curled. Chloroplasts were scarce and had a tendency to assemble near the end, rather than along the lateral walls (fig. 8), and nuclei were

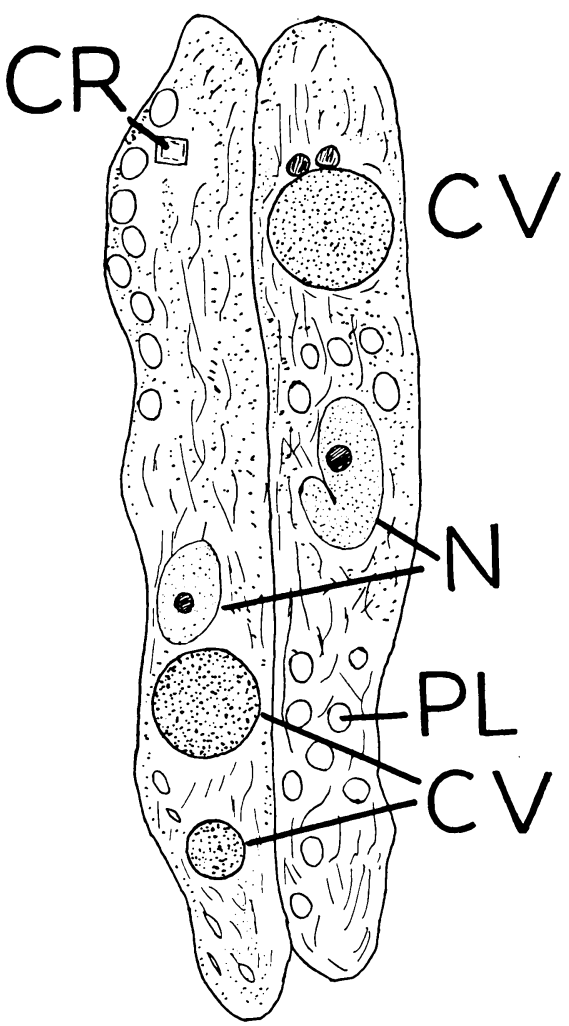

Fig. 8.-Palisade parenchyma cells from the leaflet of a boron-deficient tomato plant. Hypoplasia was shown by the disintegration of cell contents, lobed nuclei, and the presence of coacervates: $C V$, coacervates; $C R$, crystal of calcium carbonate; $N$, nucleus; $P L$, plastids. Safranin and methyl green stain. sometimes swollen and lobed. The coacervates in the cell vacuoles were, however, the most conspicuous and relevant features of these cells.

If this condition of hypertrophy in parenchyma cells be due to factors which inhibit nuclear division, and cause cells to grow to excessively large dimensions, it can be connected with the disruption of the organic phosphorus complexes either in the leaf or in the stem. In the stem the first visible indications of hypoplasia due to boron deficiency are associated with the enlarged nuclei about which plastids are grouped (fig. 9). The topography of the cell indicates changes in the surface tension and osmotic pressure of the vacuolar solution. In leaves, even those only slightly affected by boron deficiency, the perivascular cells showed much more profound derangements (fig. 10). Mitochondria were unusually abundant; plastids had not developed, probably because of the adsorption of phospholipoids by coacervates had impoverished the vacuolar solution; the nucleus was swollen; and phenolic material was floating in the vacuole. The normal organization was destroyed, not by things absorbed, but by the lack of necessary complexes which in a healthy leaf are derived from the sources of supply.

It has been known since the work of Johnston and Dore (1929) that sugars and starches are more abundant in the leaves and stems of boron-deficient than in those of normal tomato plants. The formation of glucose-6-phosphate is an important step in carbohydrate metabolism representable as follows :

\section{hexokinase}

$\mathrm{PO}_{4}+$ glucose + adenosine triphosphate $\longrightarrow$ glucose-6-phosphate.

If there were a scarcity of adenosine triphosphate, the reaction would be retarded and reducing sugars would predominate. The assumption is supported 
by the findngs of Johnston and Dore. The inhibition of nucleoprotein synthesis and of carbohydrate transformation gives evidence that some important phosphorus complex was scanty in the celery-petiole and tomato-leaflet cells.

Young shoots which grew from accessory buds after the death of the main shoot of boron-deficient plants afforded material for histological and cytological studies of the apical meristem and embryonic leaves. Longitudinal sections of the apical region (figs. 11 and 12) reveal the extent to which growth and development were disrupted in the meristematic regions. In the apical dome the polyhedral cells containing dense granular cytoplasm and large nuclei had maintained their integrity. Supplies of hexose sugars and amino acids can reach such cells from the subjacent cells. Growth was due to cell multiplication rather than cell enlargement. The equilibrium between oxidation and reduction would be maintained by the presence of adequate hydrogen donors, as shown by the absence of phenolic inclusions. At the base of the primordium the meristem gave rise to cells which expanded rapidly, with simultaneous enlargement of the vacuoles. But indications of hypoplasia were apparent near the base of the primordium, where the contents had contracted and the cells were compressed; necrosis followed. Many of the cells which were able to survive were hypertrophied, a condition resembling that previously observed in the meristematic region of zinc-deficient peach

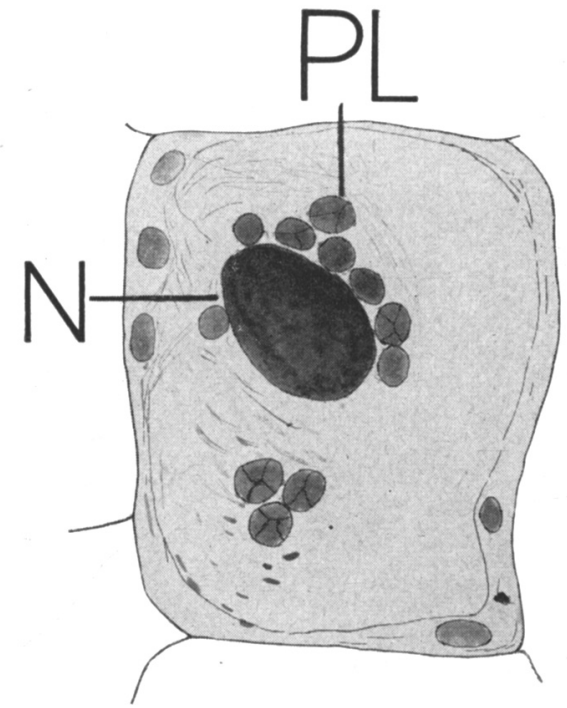

Fig. 9.-An incipient stage of hyperplasia resulting from boron deficiency in a postmeristematic cell of a tomato stem. Abnormality is indicated by the grouping of plastids, $P L$, around the nucleus, $N$. Several plastids contained starch grains. Fixed with Meves solution; stained with iron alum haematoxylin. trees (Reed, 1941). It should be noted, however, that the primordia of borondeficient celery, on account of low oxidase activity, contained a minimum of phenolic compounds.

Intense symptoms of injury were obvious in the leaf primordia of celery. Cells at the base were greatly enlarged, the separate vacuoles had coalesced into a single large vacuole, and lysis of their contents ensued (fig. 11). Layers of black, necrotic material appeared in the leaf primordia. These replaced the tissue which should have developed into mesophyll and palisade parenchyma, and betokened the oncoming death of the leaf rudiments. Emphasis should be laid on the fact that cessation of cell division and hypertrophy are the first indications of injury in embryonic tissues, whether of leaf or stem (fig. 12).

Figure 13 represents a lateral, not a median, section of another affected stem apex. The collapsed cells $(B)$ stained green, the necrotic cells red, with safranin and fast green. (Safranin is a basic dye which is valuable as a protein stain in plants.) 
The cells of the primary meristem were generally healthy, and their contents were normal for such cells. Below them hypertrophy was evident, the healthy nuclei absorbed fast green, the injured nuclei safranin, as they do in hypoplastic cells. Surrounding this primordium there was a layer of collapsed cells whose walls stained green, the remains of their protoplasm deep pink. The cells of the leaf primordia were not so seriously deranged except that they contained filamentous mitochondria, had no plastids, and in a few places were

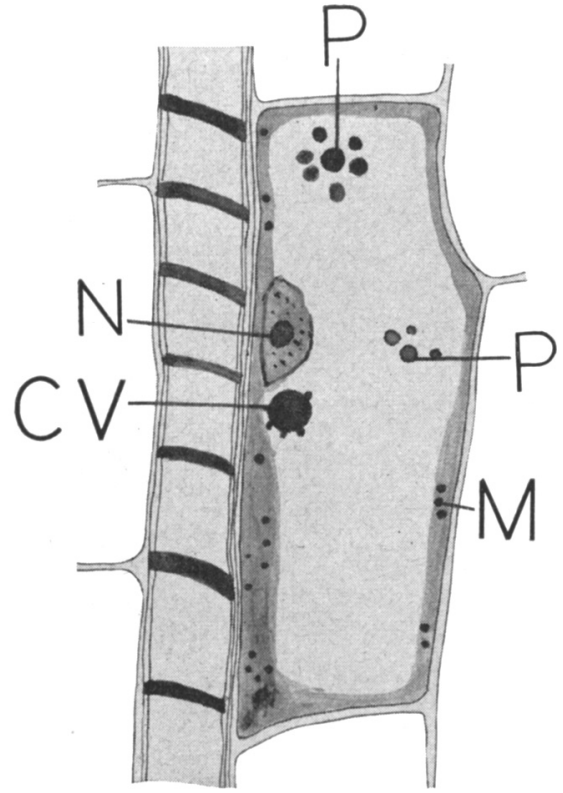

Fig. 10.-A perivascular cell from a leaf of a tomato plant severely affected by boron deficiency: $C V$, coacervate; $M$, mitochondria; $N$, nucleus ; $P$, phenolic precipitates. Fixed in zinc chloride plus 2 per cent formalin; stained with molybdenic acid reagent. droxyphenyl-alanine is no longer protected against irreversible dehydrogenation, but undergoes successive changes, eventually being converted into melanins. These dark compounds are often absorbed by the nuclei and the cell walls, giving a fresh unstained section the appearance of a histological preparation stained with haematoxylin. From our knowledge of the chemistry of melanin formation it seems likely that a transitory red stain is the precursor of the black tyrosine, being first converted into dihydroxyphenyl-alanine, then eventually to melanin. When in excess in the roots of plants like beets, turnips, and radishes, it gives rise to the conditions commonly known as black heart.

This problem of the relation of boron to the growth and development of the apical meristem has been studied in detail by Beckenbach (1944). Tomato plants which had received 0.5 p.p.m. of boron until the first blooms appeared, thereafter received differential boron treatments $-0,0.005,0.5$, and 10.0 


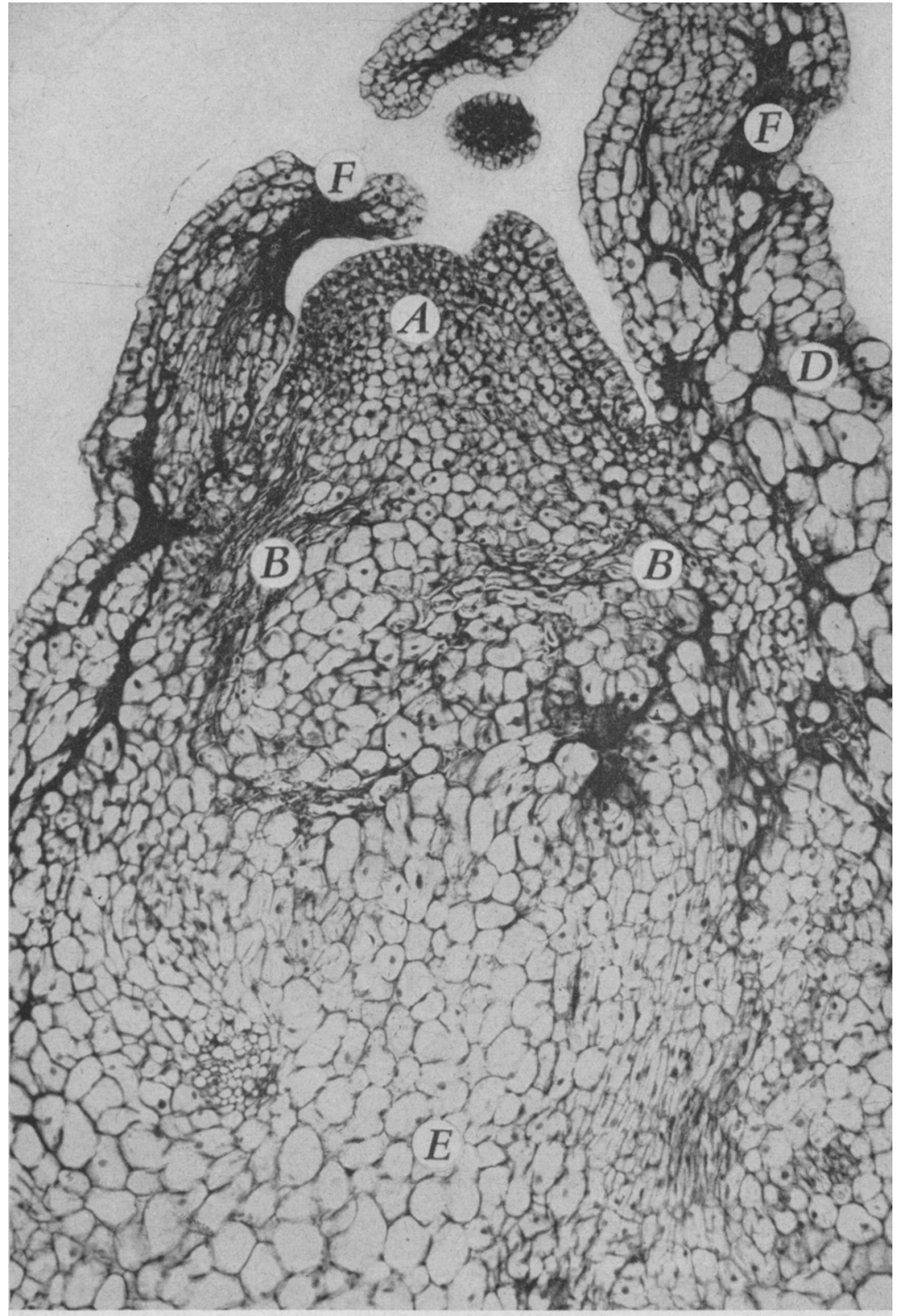

Fig. 11.-A pical region of a shoot of a boron-deficient celery plant. Parenchyma cells beneath the apical meristem were hypertrophied and (at the left) had collapsed. $A$, Nuclei hyperchromatic, cytoplasm vacuolated, vacuoles generally polar; $B$, collapsed cells whose contents were stained deep pink; $D$, cells which contained filamentous mitochondria but no plastids; $E$, hypertrophied cells; $F$, necrotic tissue. Stained with safranin and methyl green. 


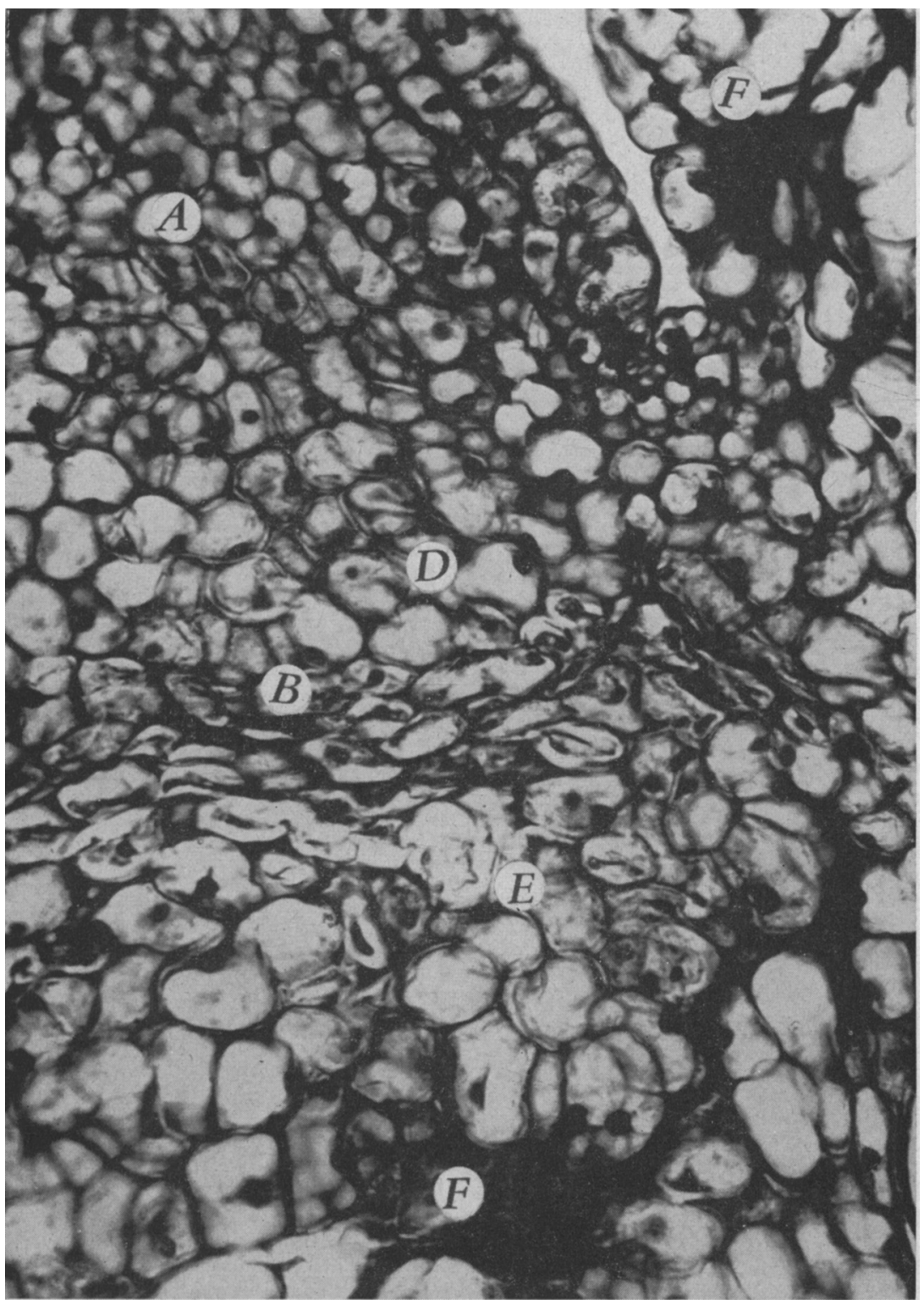

Fig. 12.-Cytological features of the postmeristematic region of a celery shoot showing effects of boron deficiency: $A$, vacuolization and incipient collapse of cells; $B$, collapsed cells; $D$, cells containing large central vacuoles, hyperchromatic nuclei and filamentous mitochondria; $E$, hypertrophied cells; $F$, necrotic tissue. $(\times 445$.) Haematoxylin stain. 


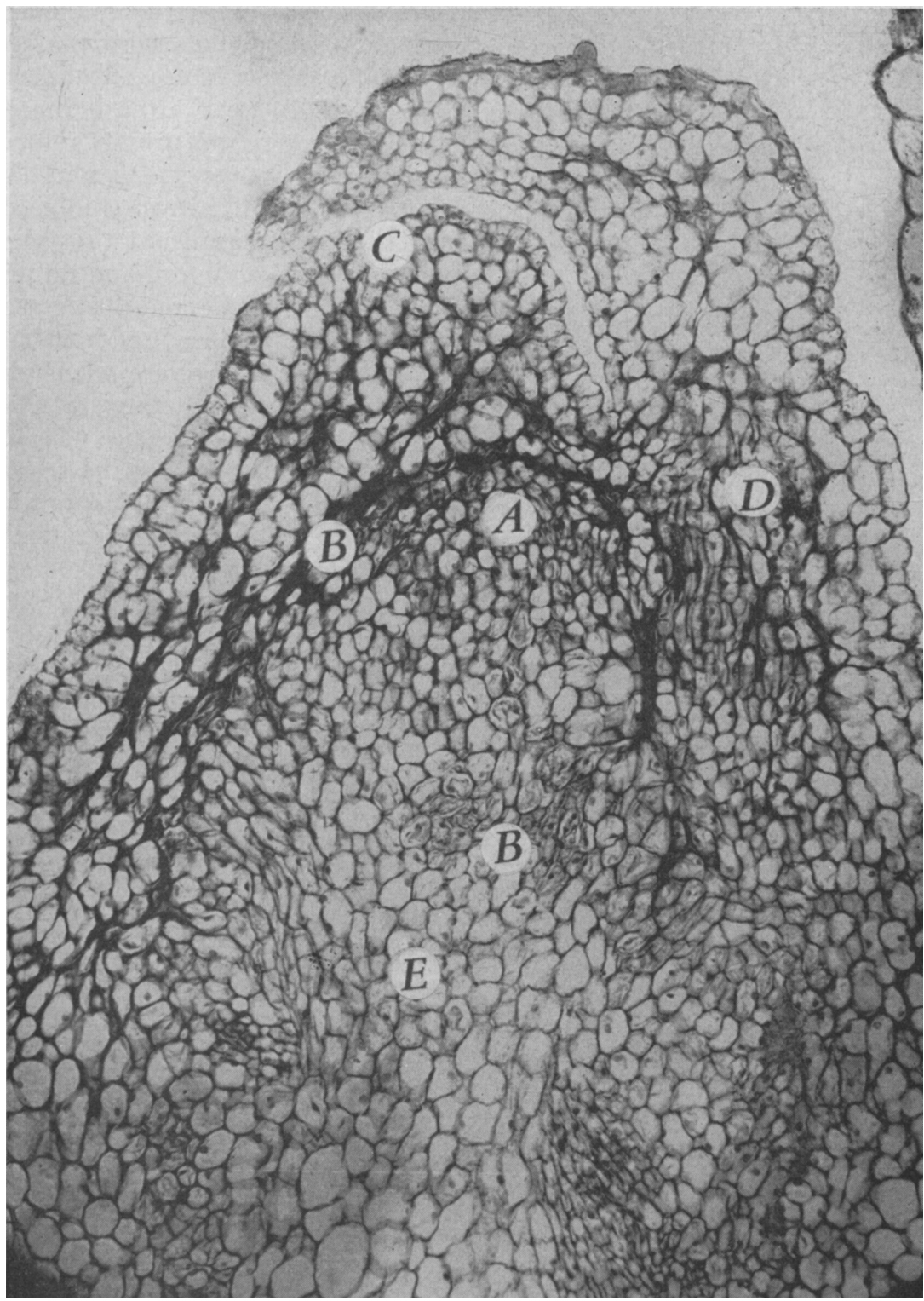

Fig. 13.-Apical region of a shoot of a boron-deficient celery plant; lateral section shows conspicuous layers of collapsed, necrotic cells: $A$, cells apparently healthy ; $B$, collapsed cells whose contents were stained deep pink; $C$, cells which contained floceulent or granular phenolic compounds ; $D$, cells which contained filamentous mitochondria, but no plastids; $E$, hypertrophied cells. Stained with safranin and fast green. 


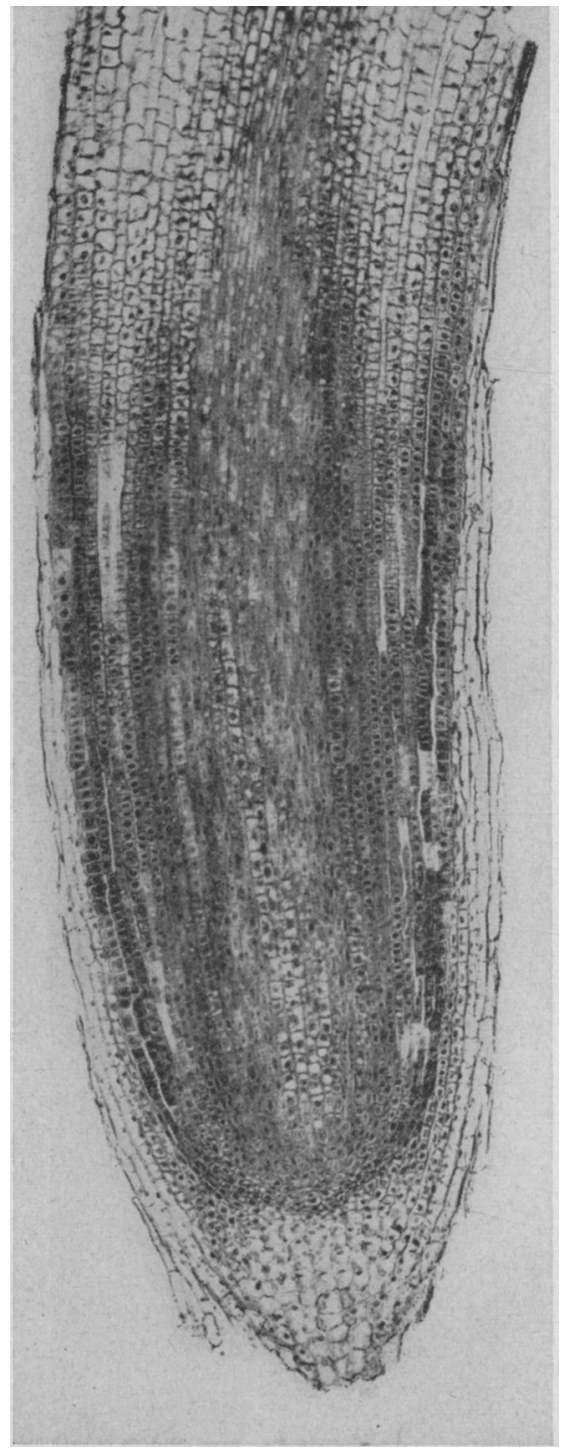

Fig. 14.-Apical region of a healthy celery root. ( $\times 130$.$) Acid fuchsin and$ methyl green stain. p.p.m. From an earlier stage the milliequivalent proportions of nitrate, phosphate, and sulfate in the cultures were also varied. A week after boron was withheld, growth was greatly retarded in all series, except where phosphate was high and both nitrate and sulfate were low. It is significant that plants which received no boron and no phosphate became brittle and bushy at the growing point, while injury from boron deficiency was less severe when phosphate was high. When growth was rapid owing to the presence of a high concentration of nitrates, the requirement for boron was high. Plants which received high phosphate were taller but had fewer side shoots; this indicates the dominance of the apical meristem over lateral buds. The rate of growth of the apical meristem was rather uniform in most cultures where the plants received boron, regardless of the amount added, if the nitrate supply was adequate.The linkage with nitrates suggested that boron is essential for normal protein synthesis through its effect on the utilization of carbohydrates. The number of meristems 1 inch or longer per plant did not vary in proportion to the amount of boron supplied.

Reed and Dufrénoy (1935) showed that the ability of the meristem of the orange shoot to maintain its rate of growth can be correlated with the mobilization of zine in the meristem at the expense of postmeristematic cells. When supplies of an essential element fall below a minimum, distortion of the growth and development occurs, but the cells compensate for the deficiency in many ways-for example, by an abeyance of the expensive synthesis of new nucleoprotein, hydration of biocolloids, and accelerated respiration, all of which contribute to delay growth and differentiation.

Root tips from celery plants grown in nutrient solution were crushed on a slide, treated with the molybdenic acid reagent, and examined under high magnification. Absence of blue color in the roots of healthy plants indicated 
a low level of phosphate compounds, since they had flowed to sinks in the shoots and leaves. The dark blue of the stele of boron-deficient roots, on the other hand, indicated a high level of phosphate compounds; the extra-stelar

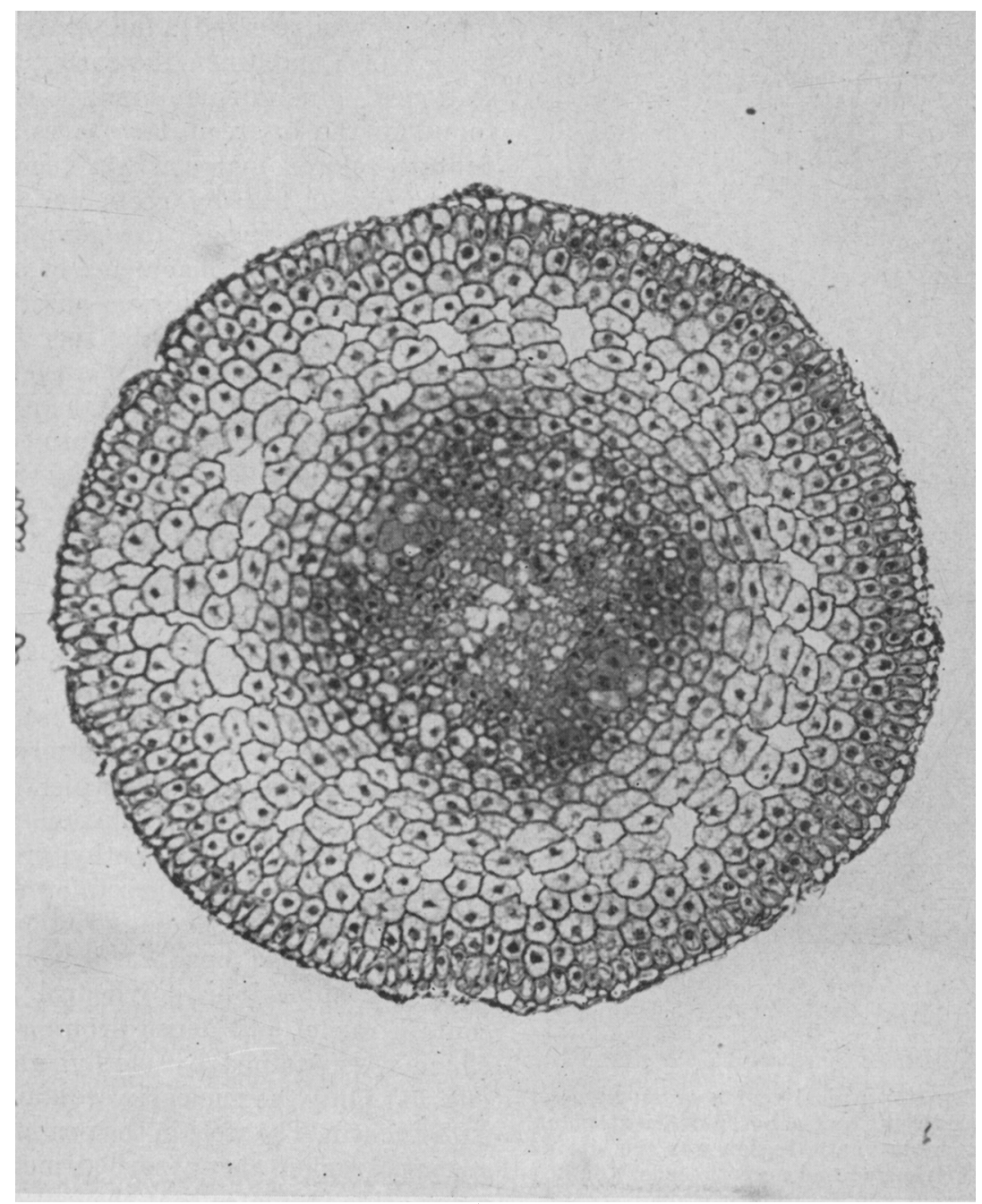

Fig. 15.-Transection of the postmeristematic region of a healthy celery root. ( $\times 185$.$) Acid fuchsin and methyl green stain.$

tissues were faint blue. The endodermis and pericycle formed a definite boundary between the two zones. The boron-deficient roots released phosphates into the reagent after a few hours but none was observed to come from the healthy roots. Within this cylinder, the stele of boron-deficient roots had a high level of energy-rich phosphorus compounds, giving its cells the ability to maintain a low residual oxidase activity because the phosphate complexes could act as dehydrogenases. Outside of this cylinder, the cortical cells were 


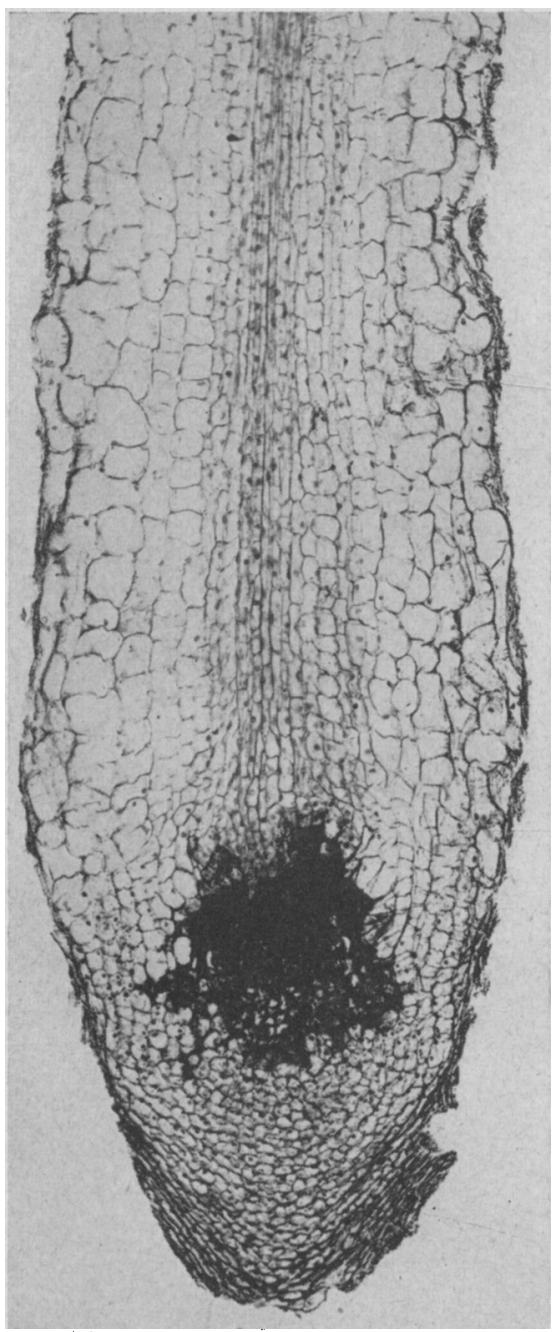

Fig. 16.-Apical region of an affected celery root from a boron-deficient plant. The meristematic region was the site of hypertrophied and necrotic cells. $(\times 130$. Safranin and fast green stain. relatively poor in such compounds but rich in eatechol and catechol oxidase. Polyphenol oxidase was present in the cortical cells of the boron-deficient roots. It was released abundantly by these roots; and when the cortex was sectioned, blue-purple deposits were found in the intercellular spaces. No definite colored material was seen in the cortex of healthy roots nor was there much evidence of oxidase which had been released. No evidence of phenol oxidase in the stele was observed in either case. These results therefore demonstrate that oxidase is more active in the affected roots and that the phosphates in them do not enter into complexes, but rather remain as phosphate ions. They also show that the cells in these tissues of boron-deficient plants became, to a varying extent, more permeable to the phosphate ions, which normally pass slowly through cytoplasm.

Verification of the above observations was obtained from a study of healthy and affected roots which had been fixed in Nemec's solution and stained with fuchsin and methyl green, with safranin and fast green, or with haematoxylin after being sectioned. Cells of the apical meristem of healthy roots are cubical or polyhedral and contain nuclei and dense protoplasm, which were stained by methyl green (fig.14). Only the nucleoli were stained with fuchsin. The stele in the postmeristematic region also absorbed methyl green; this indicates that the cell contents were well supplied with complex

synthates and that the water phase was well distributed through the protoplasmic material (fig. 15). The thinness of the walls is evidence that they were under tension as a result of the growth of cell contents. The cortical cells were likewise healthy; their walls were thin and somewhat rounded at the corners. Only the outer layers were stained with safranin.

The cells of boron-deficient roots show several contrasts to the foregoing conditions. Figures 16 and 17 indicate some of the derangements which were evident when sections of the roots had been stained by the technique used for 
the healthy roots. The undifferentiated cells of the apical primordium showed few abnormalities, but the stele in the postmeristematic region showed evident injury. A thickening of cell walls indicated excessive hydration of cellulose and related substances. The young sieve tubes were full of material stainable with fast green, and older collapsed cells were densely stained with safranin. The oil ducts in the phloem were intact though the rest of that tissue was necrotic. Haematoxylin also stained the stele intensely. Outside the endo-

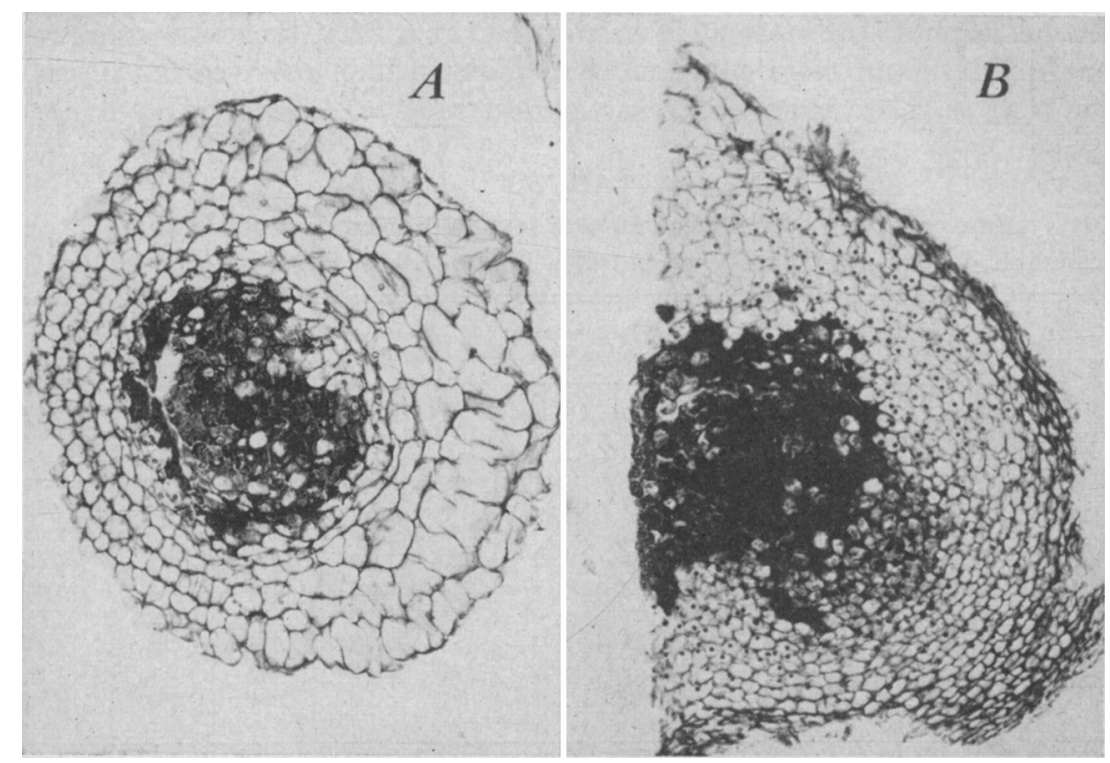

Fig. 17.-Transections of the postmeristematic region of affected roots from boron-deficient celery plants : $A$, stained with safranin and fast green; $B$, stained with haematoxylin. $(\times 185$.

dermis and pericycle, the cells of the cortex appeared healthy at the stage at which this material was collected, though ultimately it became gelatinous and the roots perished. The cell walls were thin, vacuoles clear, nuclei stainable with safranin or haematoxylin, and prochromosomes clearly evident.

\section{RADISH}

The specific symptoms of boron deficiency in the radish are retarded growth, chlorotic leaves, distorted roots, and black necrotic tissue in the interior of the roots. H. E. Thomas brought from certain market gardens, specimens showing those symptoms. These served as a source of material for laboratory studies. Subsequently plants were raised in iron tanks containing nutrient solutions whose boron contents were $0,0.05,0.1$, and 0.5 p.p.m. When harvested, the plants from solutions containing boron had produced flowers, but root development in the solution cultures was not so good as it would have been in soil. The data in table 1 show, however, that boron is necessary for the complete development of the plant, though the amounts added were small. Without boron there was a preponderance of yellow leaves, few fleshy roots, and no flowers. 
Scripture and McHargue (1945) concluded from their study of the radish plant that boron is evidently essential for its normal carbohydrate metabolism.

The opportunity for biochemical tests on the plants was so limited that no definite conclusions could be drawn. However, the rootlets of radish plants from zero boron solutions had a stronger oxidase activity, when tested with the thydi reagent, than those from healthy plants from the 0.5 p.p.m. boron solutions, a result confirming that obtained with celery roots. The case was somewhat different, however, when sections of the fleshy roots were examined with the same reagent. In the roots it was quite evident that there was more polyphenol oxidase and more pyridoxine in plants which received 0.5 p.p.m. of boron than in those which had received no boron.

TABLE 1

Relation of Boron to Growth of Radishes in Nutrient Solutions

(Germinated June 27, 1944; installed in tanks July 19, 1944 ; harvested August 12, 1944)

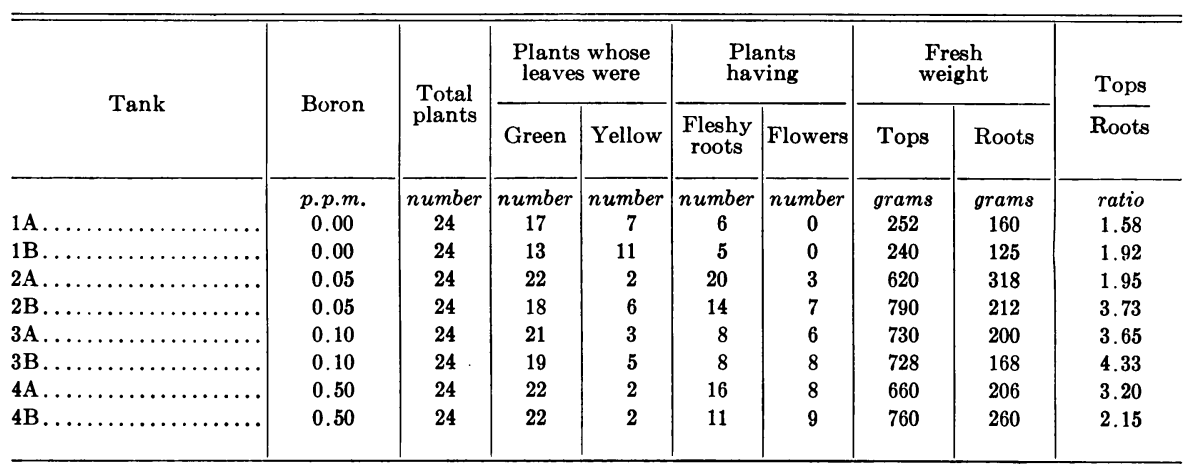

Petioles of the radish leaves were examined for the presence of inorganic phosphate by the Gomori method. The walls of the xylem and phloem tissues of healthy plants were blackened but their contents were not. In borondeficient plants, the nuclei of the cortical cells were light gray and clear; the brownish-black color of the disorganized contents of the phloem cells indicated that the cells contained inorganic phosphate ions. The evidence thus far obtained leads to the conclusion that the deficiency of a microelement like boron is coupled with an excess of phosphatase which can hydrolyze phosphorous esters.

\section{SUNFLOWER}

Several new aspects of the boron-deficiency problem have been gained from a study of the sunflower, which is known to have a definite and rather high requirement for boron. Its rapid growth and adaptability to experimental technique have made it a useful plant for many kinds of physiological investigations.

In the present study the plants grew from the seedling stage in nutrient solutions of purified salts which differed only in the amounts of boron they contained. Plants in solutions which received no boron ceased to grow after two or three leaves had been formed, and eventually perished. Plants in solutions which received 0.5 p.p.m. of boron at the outset and additional doses 
as the original supply was exhausted were thrifty, had good foliage, produced flowers, and matured seeds. Plants in the intermediate concentrations made limited growth and eventually showed chlorosis and thickened veins in the leaves.

The data in table 2 give further indication of the essentiality of boron. The experiment was conducted in large cast-iron tanks of aerated nutrient solutions, under favorable illumination in the greenhouse. The concentrations of boron supplied are given in the first column of table 2 . The green weights of tops and roots in concentrations of 0.05 and 0.10 p.p.m. of boron were not significantly different, an indication that both concentrations were below some threshold value needed for the synthesis of a substrate for growth. Colwell

TABLE 2

Relation of Boron to Growth of Sunflow ERS IN NUtrient Solutions

(Planted October 12, 1944; harvested November 11, 1944)

\begin{tabular}{c|c|c|c|c}
\hline \multirow{2}{*}{ Boron } & \multirow{2}{*}{$\begin{array}{c}\text { Total } \\
\text { plants }\end{array}$} & \multicolumn{2}{|c|}{ Average fresh weight } & \multirow{2}{*}{$\frac{\text { Tops }}{\text { Roots }}$} \\
\cline { 2 - 3 } & & Tops & Roots & \\
\cline { 2 - 3 } & number & grams & grams & ratio \\
0.00 & 19 & 4.3 & 3.1 & 1.4 \\
0.05 & 24 & 29.2 & 6.7 & 4.3 \\
0.10 & 21 & 29.0 & 7.1 & 4.1 \\
0.50 & 19 & 40.5 & 10.0 & 4.1 \\
\hline
\end{tabular}

(1943), who estimated the response of sunflowers to boron by an index of age values, found a similar equivalence of growth for 0.05 and 0.10 p.p.m. boron. Johnston and Dore (1929) likewise found no differences in the height growth of tomato plants for the first 3 weeks in culture solutions receiving 0.011 and 0.55 p.p.m. boron. Subsequently, growth in the lower concentration ceased, but in the higher it continued although at a slightly decreased rate.

The data in table 2 also show a similarity in the ratio of weight of tops to roots in all except the plants from solutions which received no boron. Since root growth bears an intimate relation to the supplies of synthates furnished by the leaves, boron must have some important rôle in their function, a conclusion supported in several ways by an inspection of figure 17 .

Histological Symptoms of Sunflower Stems. The subapical region of affected sunflower plants, like those in figure 18, $B$, was hypertrophied by the formation of a thick layer of large-celled undifferentiated parenchyma between xylem and phloem (fig. 19), similar in several respects to that in borondeficient Vicia faba (Warington, 1926), Brassica (Löhnis, 1940), and tomato (Johnston and Dore, 1929). The swelling of the sunflower stems became conspicuous after the death of the apical bud. It had some histological resemblance to the proliferated tissue of certain plant galls resulting from insect punctures-tissue which Küster (1930) designated as secondary. Walker (1943) has clearly described this phenomenon in Beta and Brassica affected by boron deficiency.

The cells of the undifferentiated parenchyma in sunflowers were initially hexagonal in transverse section but soon became elongated in the radial direc- 


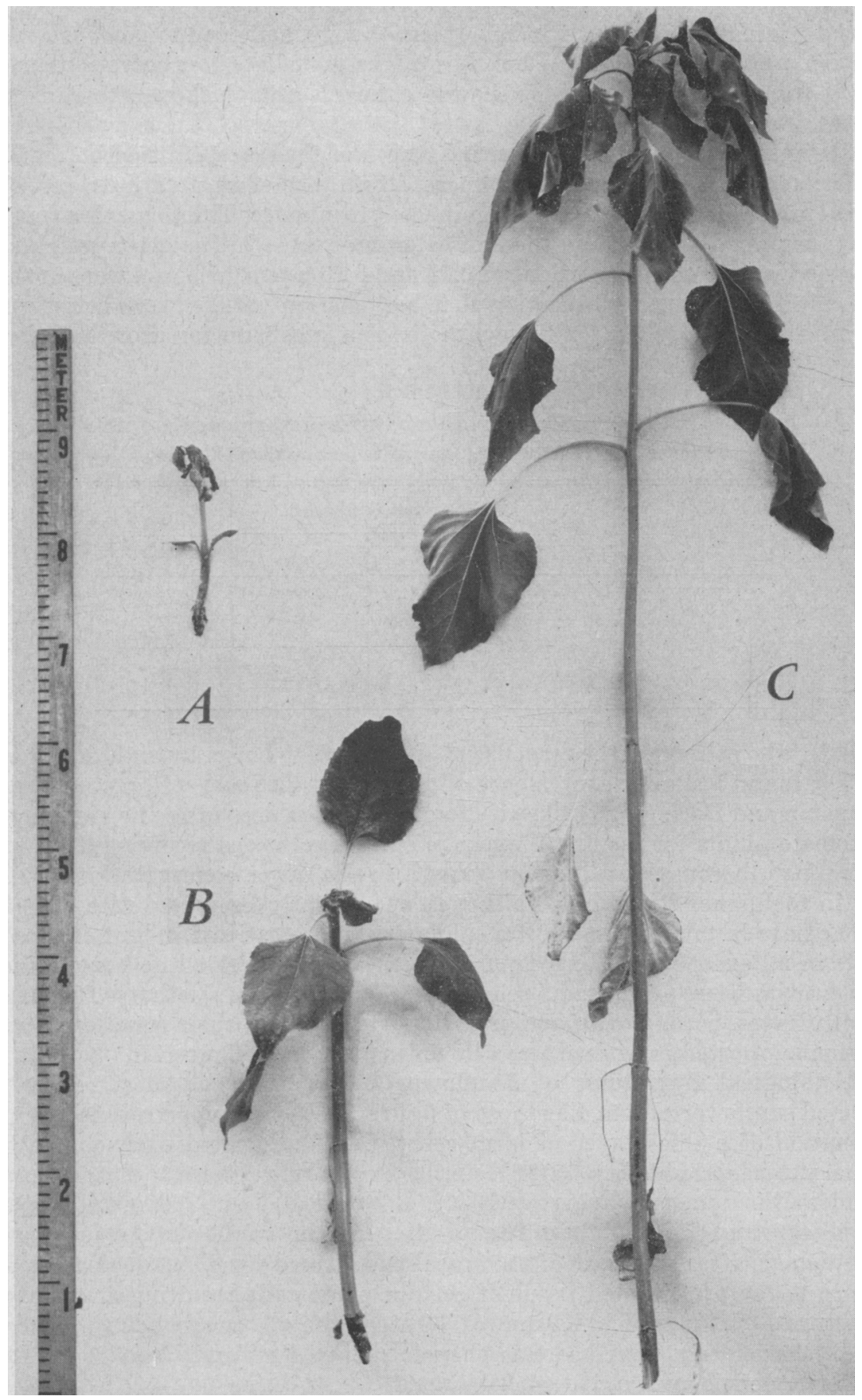

Fig. 18.-Sunflower plants from solution cultures in the greenhouse: $A$, from solution without boron; $B$, from solution containing 0.05 p.p.m. boron ; $C$, from solution containing 0.5 p.p.m. boron. (The leaves wilted while the photograph was being made.) 


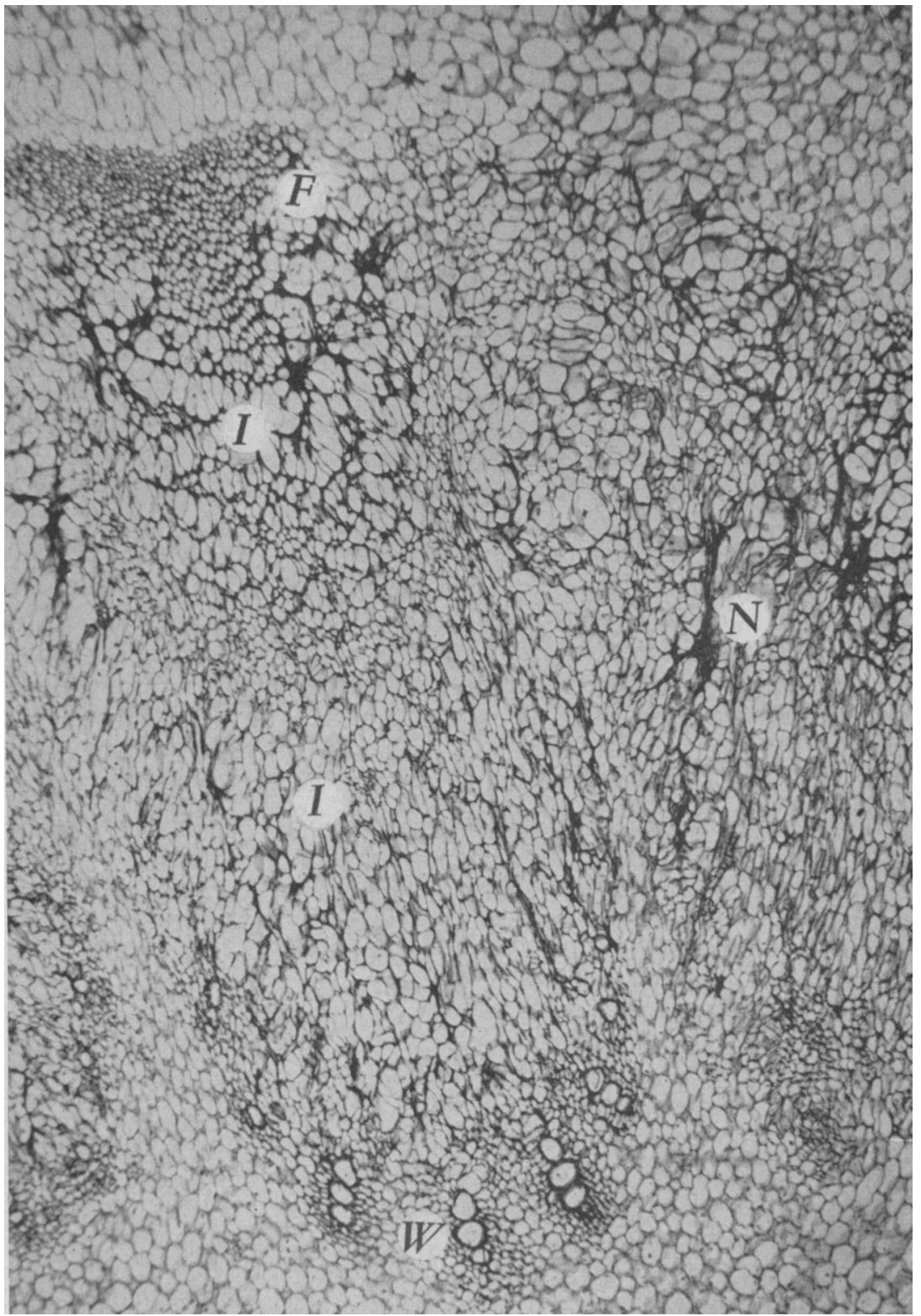

Fig. 19.-Section of a sunflower stem showing later stages of boron deficiency in which there is a thick layer of undifferentiated parenchyma: $F$, phloem; $I$, undifferentiated parenchyma; $N$, necrotic tissue; $W$, xylem. $(\times 70$.$) Safranin and fast green$ stain. 
tion. Their nuclei were flattened ovoids lying adjacent to the parietal cytoplasm, most of the vacuoles were optically empty, though a few contained flocculent material which was stainable with phosphomolybdate haematoxylin. Neutral red was not readily absorbed by living cells, but methylene blue was quickly absorbed, an indication that the vacuolar solution was acidic and low in hydrogenases. In more advanced stages of hypertrophy there were radial lines of crushed cells in the cross sections, probably due to tensions set up by high osmotic pressure of the rapidly growing tissue. Observations of Johnston and Dore (1929), Haas (1932), and others support the idea that the enhanced turgidity of similarly affected tissues may be due to a higher content of sugar and other solutes unutilized in the growth process. When, eventually, the cytoplasmic integrity of the larger cells was destroyed by proteolysis, or simply by a disequilibrium between volume and surface, there would not be enough wall pressure to maintain their form, and collapse would ensue.

The cytological studies on the effect of boron deficiency in olive and celery had some reference to the phosphorus compounds, but boron-deficient sunflowers proved to be more suitable plants for a study of the relation of phosphate metabolism to the boron supply.

As an introduction to the problem, the percentages of total and of inorganic phosphorus in sunflower stems and leaves in two parallel experiments were determined. The determinations give a rough, over-all picture of the relations between the two forms of phosphorus in plants which received various amounts of boron (table 3). Each set of plants had grown 70 days in 15-liter tanks of nutrient solutions containing $0.00,0.05,0.10$, and 0.50 p.p.m. of boron, under conditions similar to those previously described. When the healthy plants in the higher concentrations of boron were in flower, the stems and leaves of each set were harvested, separated, and dried. The dried samples were ground and analyzed by J. Katz. Total phosphorus was determined by the dry ignition method with $\mathrm{Mg}\left(\mathrm{NO}_{3}\right)_{2}$. The inorganic phosphate was extracted from aliquots of the dried samples with 2 per cent acetic acid. Phosphate was determined colorimetrically by Allen's method.

The data (table 3) consistently show a greater percentage of phosphorus compounds in the dwarfed chlorotic plants which had inadequate boron. The larger, healthy plants which received adequate amounts of boron diluted the inorganic constituents according to a well-known principle.

Of greater importance is the ratio between inorganic and total phosphorus in the several lots of plants. The analyses of stems show that over 90 per cent of the phosphorus in the zero-boron plants was inorganic phosphorus and that with increasing amounts of added boron, the ratios of inorganic to total phosphorus decreased to about 50 per cent. This is strong evidence of higher phosphatase activity in the tissues of the affected plants, which could result in the release of the energy of phosphate esters for the maintenance of the plants. Albaum and Umbreit (1943) demonstrated an increase in inorganic phosphorus beginning about the seventy-second hour of growth of the oat embryo concomitant with gradually increasing metabolic activity.

The functional relation between phosphate and boron described by Beckenbach (1944) was discussed earlier in this paper, but may be mentioned here in considering the results of these analyses. 
The phosphate content of healthy is less than that of affected stems, as shown by relatively simple tests with molybdenic reagent on sections of fresh material. The characteristic blue color appeared only in the hypodermal collenchyma when sections of healthy stems ( 0.5 p.p.m. boron) were immersed in this reagent, but the blue color appeared in the cortex and undifferentiated parenchyma when sections of stems of boron-deficient plants were similarly treated. Moreover, the reagent in which the sections were immersed was also blue, indicating that they contained diffusible phosphates.

Confirmatory results were obtained by application of the Gomori test on fresh sections of the postmeristematic regions of stems. Healthy material contained little of the black substance except in the walls of xylem and phloem

TABLE 3

Total and Inorganic Phosphorus in 70-Day-Old Sunflower Stems and Leaves as Percentages of Dry Weight

\begin{tabular}{|c|c|c|c|c|c|c|}
\hline \multirow{3}{*}{ Boron supplied } & \multicolumn{3}{|c|}{ In stems } & \multicolumn{3}{|c|}{ In leaves } \\
\hline & \multirow{2}{*}{$\begin{array}{c}\text { Total } \\
\text { phosphorus }\end{array}$} & \multirow{2}{*}{$\begin{array}{c}\text { Inorganic } \\
\text { phosphorus }\end{array}$} & \multirow{2}{*}{$\frac{\text { Inorganic } \mathrm{P}}{\text { Total } \mathrm{P}}$} & \multirow{2}{*}{$\begin{array}{c}\text { Total } \\
\text { phosphorus }\end{array}$} & \multirow{2}{*}{$\begin{array}{c}\text { Inorganic } \\
\text { phosphorus }\end{array}$} & Inorganic $\mathrm{P}$ \\
\hline & & & & & & Total P \\
\hline $\begin{array}{c}\text { p.p.m. } \\
0.00 \ldots \ldots \ldots \ldots \ldots \ldots \ldots\end{array}$ & $\begin{array}{l}\text { per cent } \\
0.90\end{array}$ & $\begin{array}{l}\text { per cent } \\
0.83\end{array}$ & $\begin{array}{c}\text { ratio } \\
0.92\end{array}$ & $\begin{array}{l}\text { per cent } \\
0.69\end{array}$ & $\begin{array}{l}\text { per cent } \\
0.55\end{array}$ & $\begin{array}{l}\text { ratio } \\
0.80\end{array}$ \\
\hline $.05 \ldots \ldots \ldots \ldots \ldots \ldots$ & .40 & .31 & .77 & .48 & .32 & .67 \\
\hline $.10 \ldots \ldots \ldots \ldots \ldots \ldots$ & .49 & .41 & .84 & .49 & .35 & .71 \\
\hline $0.50 \ldots \ldots \ldots \ldots \ldots \ldots$ & 0.29 & 0.15 & 0.52 & 0.37 & 0.23 & 0.62 \\
\hline
\end{tabular}

elements, which probably represented phosphate in transit. Sections of borondeficient plants tested in the same way also exhibited an intense brown-black color in cortex, phloem, and xylem and, in addition, similar (though weaker) color in the undifferentiated and in the central parenchyma. Not only were the cell walls black, but the cells contained minute black granules. Intact phloem elements (chiefly sieve tubes) and cortical parenchyma contained large numbers of the same type of black granules. Comparative tests on similar experimental material which grew in the autumn when illumination was weak, verified the foregoing observations.

Summing up these histochemical tests we may say that the boron-deficient sunflower stems contained more ionic phosphate than the healthy and that the excess was chiefly in the parenchyma of the cortex and undifferentiated layers. Since they are active metabolic tissues it is significant that they were the site of such rapid phosphate turnover in the affected plants.

A paper by Yin (1945), which came to hand after the foregoing observations were made, corroborates these conclusions by demonstrating a high level of phosphatase activity in the meristematic tissues, the outer layers of the cortical parenchyma, and the phloem elements. He rightly emphasizes the importance of phloem elements in view of their role as conduits for the transport of organic materials and of phosphorus compounds.

The enhancement of phosphatase activity in stems of boron-deficient sunflowers was demonstrated by the use of Willmer's modification of Gomori's test (Willmer, 1942). Fresh sections of the apical regions of healthy and boron- 
deficient plants were used. The latter showed distortion and incipient necrosis. The sections, after fixation and hydration, were transferred to a solution composed of 2 per cent $\mathrm{CaCl}_{2}, 1$ part ; 2 per cent barbital, 2 parts ; 2 per cent sodium glycerophosphate, 2 parts; water, 5 parts; in this they were incubated at $40^{\circ} \mathrm{C}$. There was no indication of phosphatase in the healthy stems, but the blackened proxylem and protophloem of the affected stems gave definite indication of phosphatase. Similar tests conducted on sections of petioles also demonstrated that the phloem and xylem of affected plants were richer in phosphatase than the healthy.

It is important to ascertain whether such processes as glycolysis, oxidoreduction, and the transformation of phosphorus compounds can be linked up. The postmeristematic region of the sunflower stem obviously affords suitable material for such an inquiry. If the oxidase activity in such tissues is below normal and sugars are being consumed at a low rate, we may reasonably infer that the activity of the phosphatase is noncompensated by the catalysts which, coupled with oxidation, could otherwise build up phosphate esters. Vogler and Umbreit (1942) found that the oxidative phase was accompanied by phosphate fixation, and the reductive phase of carbon fixation by a release of phosphate.

In pursuance of this idea, I investigated the ability of fresh sections of sunflower stems to reduce brilliant cresyl blue, Bindschedler's green, and methylene blue in sealed hanging drops. Brilliant cresyl blue dissolved in barbiturate buffer at $\mathrm{pH} 7.1$ was reduced with the formation of a precipitate only by sieve tubes and undifferentiated parenchyma of boron-deficient plants. In healthy material, on the other hand, reduction was observed in sieve tubes, bast, and xylem parenchyma, with the formation of precipitates. This dye penetrated the vacuoles of collenchyma cells of healthy, but not of affected plants. It penetrated and stained the nuclei of healthy pith parenchyma, but was not reduced. Bindschedler's green was slightly reduced by the fibrovascular bundles. Methylene blue was reduced by the undifferentiated parenchyma of both healthy and affected plants but not by the phloem of either healthy or affected plants. The hydrogenase activity in the affected plants is therefore confined mainly to the phloem and undifferentiated parenchyma, where, as shown above, there was the greatest release of phosphate, accompanied by a release of energy which would be available for maintaining the work of the cell.

The oxidases of the stem show a distribution which is significant for the cytochemical appraisal of healthy and affected plants. Fresh sections of stems were immersed in thydi reagent in watch glasses and transferred, after the color appeared, to slides, and examined under the microscope. The indophenol blue formed more rapidly in sections of affected plants which, although they had received 0.05 p.p.m. boron, showed typical deficiency effects, indicating a higher level of oxidase activity than the healthy plants. In the healthy sections the blue retained was principally in phloem elements; the central pith cells were initially blue, but lost the color by diffusion. The phloem elements, the adjacent undifferentiated parenchyma, and the pith of the boron-deficient plants were deep blue. Upon longer exposure the cortex absorbed the thydi reagent, but the blue color was very faint. 
Similar sections were tested for oxidizing substances by a solution containing 100 p.p.m. of $a$-naphthylamine. There was no color change in sections of healthy plants, except in the bast fibers; whereas in the boron-deficient there was an intense reddish-purple color only in the vacuoles of undifferentiated parenchyma cells between phloem and xylem. Supplementary tests were made with benzidine base slightly acidified with acetic acid, which, upon oxidation, gives a brown-black color. The fibrovascular bundles of healthy and affected stems were stained dark brown after 24 hours, and the undifferentiated parenchyma of the latter was dark lavender.

These observations indicate that the stems of boron-deficient plants had a higher level of oxidase activity than normal. The principal site was in the fibrovascular and undifferentiated parenchyma tissues, with a distinct, though lower, level in the cortex.

The equilibrium between phosphatase and polyphenol oxidase would be continually shifting as the injury to the plants became more severe, parallel with correlative changes in other activities which would tend to minimize the effects of derangements in nutrition. The ways in which the energy released from phosphate esters is utilized cannot at present be stated.

Further information on the condition of the cells of healthy and of affected stems of sunflower plants was obtained from observations on fresh sections of the postmeristematic region which were treated with certain acidic or basic dyes. The technique has been profitably employed by many investigators, since modern research has elucidated the nature and chemistry of the dyes.

The acid dyes employed were vital red, Congo red, Martius yellow, acid fuchsin, and eosin ; the basic dyes were methyl green, methylene blue, neutral red (weakly basic), safranin, and Nile blue A.

Congo red and eosin gave the most definite reactions; acid fuchsin faded unless a few drops of citric acid solution were added, giving it a reaction of $\mathrm{pH}$ 3.6. The other dyes were dissolved in Ringer's solution having a reaction of $\mathrm{pH}$ 8.0. Basic dyes which gave the most definite results were safranin, Nile blue A, methylene blue, and methyl green. The epidermal cells of borondeficient plants seldom absorbed dyes, but the collenchyma walls readily absorbed them regardless of the boron supply. Eosin was the only acid dye to penetrate the cells of the cortical parenchyma, and none of the basic dyes penetrated. None of the dyes penetrated the cells of the bundle sheath or of the cambium. The phloem elements absorbed basic more readily than acid dyes, though eosin was absorbed by the phloem of boron-deficient plants. The cells of the undifferentiated parenchyma and of the central pith appeared to be basic, since they readily absorbed the acid dyes Congo red and eosin. Tracheid walls absorbed both acid and basic dyes. Methyl green and safranin penetrated and stained the nuclei of the central pith without accumulating in the vacuoles or staining the cytoplasm.

The results of the various cytochemical tests are summarized in table 4 .

Cytological Features of Sunflower Leaves. The leaves of sunflower plants are reliable indicators of boron deficiency. Initially they are pale green, then become mottled by unequal chlorosis ; eventually the margins are inrolled and finally become necrotic. The veins are thickened, though none split open, as in the case of some plants. 
Free-hand sections of living material of affected leaves were briefly submerged in the solutions hereafter named and transferred to slides for examination with the microscope. The protoplasmic components of the spongy parenchyma cells were greatly disorganized and their vacuoles were replete with aggregated material which readily absorbed neutral red. The palisade parenchyma cells were hypertrophied, their contents disorganized, plastids were scarce, and intercellular spaces absent. Their vacuoles contained varying amounts of phenolic compounds in the form of clumped granules (usually at

TABLE 4

Cytochemical Reactions of Sunflower Stem Tissues

\begin{tabular}{|c|c|c|c|c|c|c|}
\hline \multirow{2}{*}{\multicolumn{2}{|c|}{ Dye or reagent }} & \multicolumn{5}{|c|}{ Healthy plants } \\
\hline & & Epidermis & $\begin{array}{c}\text { Cortical } \\
\text { paren- } \\
\text { chyma }\end{array}$ & Phloem & Xylem & $\begin{array}{c}\text { Pith } \\
\text { paren- } \\
\text { chyma }\end{array}$ \\
\hline \multicolumn{2}{|c|}{ 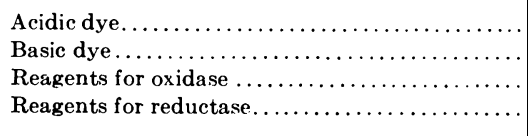 } & $\begin{array}{l}+ \\
+ \\
0 \\
0\end{array}$ & $\begin{array}{l}0 \\
+ \\
\pm \\
0\end{array}$ & $\begin{array}{l} \pm \\
+ \\
+ \\
+\end{array}$ & $\begin{array}{l}+ \\
\pm \\
\pm\end{array}$ & $\begin{array}{l}+ \\
\pm \\
+ \\
0\end{array}$ \\
\hline \multirow[b]{2}{*}{ Dye or reagent } & \multicolumn{6}{|c|}{ Boron-deficient plants } \\
\hline & Epidermis & $\begin{array}{l}\text { Cortical } \\
\text { paren- } \\
\text { chyma }\end{array}$ & Phloem & $\begin{array}{l}\text { Undifferen- } \\
\text { tiated par- } \\
\text { enchyma }\end{array}$ & Xylem & $\begin{array}{c}\text { Pith } \\
\text { paren- } \\
\text { chyma }\end{array}$ \\
\hline $\begin{array}{l}\text { Acidic dye } \ldots \ldots \ldots \ldots \ldots \ldots \ldots \ldots \\
\text { Basic dye } \ldots \ldots \ldots \ldots \ldots \ldots \ldots \ldots \\
\text { Reagents for oxidase } \ldots \ldots \ldots \ldots \ldots \ldots \\
\text { Reagents for reductase............... }\end{array}$ & $\begin{array}{l}0 \\
0 \\
0 \\
0\end{array}$ & $\begin{array}{l}0 \\
+ \\
\pm \\
0\end{array}$ & $\begin{array}{l}+ \\
+ \\
+ \\
+\end{array}$ & $\begin{array}{l}+ \\
+ \\
+ \\
\pm\end{array}$ & $\begin{array}{l}+ \\
\pm \\
+ \\
0\end{array}$ & $\begin{array}{l}0 \\
0 \\
+ \\
+\end{array}$ \\
\hline
\end{tabular}

+ , positive.

\pm , weak.

$\circlearrowleft$, negative.

one pole of the cell) or of vacuolate masses, both of which stained readily with neutral red. Lysis of the contents of those cells was common, resembling a type of proteolysis due to zinc deficiency previously described (Reed, 1938). The cell vacuoles were judged to have an acid reaction since neutral red penetrated slowly unless it was dissolved in Ringer's solution having a $\mathrm{pH}$ of 7.0 or 8.0, whereupon the dye entered rapidly and stained the vacuoles cherry red. Palisade cells which still possessed plastids were the last to be entered. Coacervates could be distinguished easily, since their external layer of phospholipid has an affinity for neutral red. They were also revealed in the palisade parenchyma of boron-deficient leaves when fresh sections were immersed in water on which a methylal-Sudan-III solution was superposed. The sections floated at the interface of the two liquids and absorbed Sudan III from the watermethylal phase. At the end of 30 minutes the sections were transferred to slides and examined with the microscope. The coacervates were discernible because the phospholipid layer was stained pink by the Sudan III. Coacervates of phenolic material were also demonstrated by the application to fresh sections of molybdenic reagent (freshly prepared), whereby the central sphere of 
phenolic compounds was rendered light brown and the phospholipid layer on the surface blue. The cytological evidence supports the idea of a noncompensated respiration in which the catechol substrate was irreversibly oxidized.

Incipient necrosis of phloem was plainly evident in sections of fixed material stained with phosphotungstic haematoxylin, but inorganic phosphates were not abundant in chlorenchyma tissue, when tested by the molybdenic reagent or by the Gomori method. This is similar to the condition found in the olive leaf. The contrast with the condition in the stems indicates that some activity peculiar to the leaf can block phosphatase activity. Further investigation of the interesting phenomenon is necessary.

Discussion of Sunflower Leaf Cytology. Everything learned about sunflower leaf cells supports the idea that the cell vacuole contains both the oxidizable phenolic compounds and an agent (polyphenol oxidase) which is able to catalyze their oxidation. In healthy, active cells the phenolic compounds are protected from irreversible oxidation by various hydrogen donors, such as ascorbic-dehydroascorbic acid or the dihydroxymaleic acid systems, to say nothing of thiol-containing groups such as cysteine and glutathione, the latter of which can serve as a reservoir of hydrogen for the cell. The balance in a healthy cell is such that the catechol particles (molecules or micelles) are randomly distributed in the vacuolar solution; but when nutrient deficiencies destroy the equilibrium between the hydrogenases and dehydrogenases, a desolvating action would occur and produce aggregates of quinones of the type observed in these cells. Wherever the quinones fail to be rehydrogenated, they will catalyze further oxidations, inhibit some links in the respiratory systems, and bring about death of the cells and formation of brown necrotic areas in the leaf. Where this rate is not so rapid as to outstrip the rate of reversible reaction, the cell or cells can survive. If the rate of quinone production is too rapid, the cells are killed. The strong activity of catechol oxidase could form positive charges on the surfaces of the phenolic precipitates which would attract the basic choline groups of the phosphatides and form an enveloping lipoidic layer which characterizes the coacervate. In other words, the formation of phenolic aggregates is due to a separation of phases caused by the desolvation of one of them.

\section{SUMMARY}

The unthrifty pathological condition of some plants may be due to the lack of one of those micronutrients formerly called "trace elements." Controlled experiments have shown that boron, although toxic in all but minute amounts, plays an important role in some of the most fundamental processes in plant cells. Characteristic deficiency symptoms appear when the amounts present or the supplying power of the soil falls below a minimum threshold value. The elucidation of certain physiological and cytological processes in relation to boron nutrition makes possible a better understanding of some fundamental problems in metabolism. None of the elements required for normal nutrition of plants acts singly, but in combination with many others; yet there are symptoms which are indicative of certain specific deficiencies. These are recognizable in the growth forms in leaf structure and in the 
quality of fruit production when other essential elements are not a limiting factor. Boron-deficient plants are dwarfed, and often the apical bud of the shoot dies. A deficiency of growth-promoting hormones has been assumed, but is not yet proved.

Boron-deficient olive trees grew slowly, and after a time the terminal buds of the shoots died; however, new shoots arose from lateral buds and made limited growth. Profound changes in the leaves were associated with a deficiency of boron; these included destruction of chlorophyll, irreversible oxidation of phenolic compounds which were polymerized to various relatively insoluble substances, and other factors which blocked the normal courses of metabolism. The bundle sheath and the sieve tubes of the phloem suffered derangements which blocked the normal conduits for the transportation of energy-rich materials in leaves.

Boron-deficient celery grew slowly. The petioles showed split veins and drying of the central tips. The leaflets were dwarfed, chlorotic, and eventually died at the margin. The roots died back from the tips. In severely affected plants, the apical buds of the shoots died and were succeeded by new shoots from accessory buds which succumbed after making a small amount of growth. Plants grown in nutrient solution containing 0.5 p.p.m. boron made healthy growths of tops and roots. It may be considered that the concentration of 0.5 p.p.m. boron is somewhere near the threshold requirement for boron in the case of celery.

The phloem region of boron-deficient petioles was the seat of high oxidase activity, and it was replete with black necrotic material. Eventually it was disrupted. Inorganic phosphates were trapped in the necrotic material in the disrupted phloem of boron-deficient plants. The parenchyma of healthy petioles maintained a lower oxidase activity than the same tissue in affected plants. Phenolic compounds in the celery seemed to escape irreversible oxidation, owing perhaps to the amounts of ascorbic acid which can act as a hydrogen donor. Melanotic substances, nevertheless, arose when the injury was severe in young shoots and roots, possibly from the oxidation of tyrosine or phenylalanine. The meristematic cells at the apex of the primordium were less affected by boron deficiency than the postmeristematic cells, in which hypoplasia and necrosis appeared early, followed soon by collapse of extensive areas. The primordia survived so long as sugars and amino acids could be translocated to them, but their existence was brief. The cells compensated in various ways for starvation-for example, hydration of biocolloids, abeyance of nucleoprotein synthesis, and accelerated respiration. The merismatic region of affected celery roots was killed early. The stele of the root had a high content of energy-rich phosphorus compounds, giving to its cells the ability to maintain a low oxidase level; hence the phosphate complexes might act as dehydrogenases. The cortical cells were richer in catechol and in catechol oxidase. Corresponding regions in healthy roots had a lower level of oxidase and phosphatase activity.

Radish plants showed clinical symptoms of boron deficiency by retardation of growth, chlorotic leaves, distorted roots which generally had black centers, and disorganized phloem in the leaf petioles.

Sunflower plants made extremely limited growth without boron, because 
of the death of the apical meristem and the chlorotic condition of the leaves. Necrosis of the apical bud preceded the formation of layers of undifferentiated parenchyma in the region between the xylem and phloem. Chlorosis of leaves and consequent impairment of photosynthetic activity was accompanied by desolvation of phenolic compounds and consequent impoverishment of the vacuolar solution.

The ratio of inorganic to total phosphorus in stem and leaves was highest in the boron-deficient plants, and çorrelatively they had a higher level of phosphatase and oxidase activity. Oxidase activity in the stems of borondeficient plants was at a higher level than in healthy plants. The cells of leaves of affected plants showed many indications of disrupted metabolism, such as hypertrophy, vacuolar aggregates of the coacervate type, and finally, lysis. 


\section{LITERATURE CITED}

Albaum, H. G., and W. W. Umbreit.

1943. Phosphorus transformations during the development of the oat embryo. Amer. Jour. Bot. 30:553-558.

BeCKeNBACH, J. R.

1944. Functional relationships between boron and various anions in the nutrition of the tomato. Florida Agr. Exp. Sta. Bul. 395:1-34.

Brenchley, W. E., and D. J. Watson.

1937. The influence of boron on the second year's growth of sugar beet affected with heartrot. Ann. Appl. Biol. 24 : 494-503.

Colwell, W. E.

1943. A biological method for determining the relative boron content of soils. Soil Sci. 56:71-94.

EsAU, Katherine.

1936. Ontogeny and structure of collenchyma and of vascular tissues in celery petioles. Hilgardia 10:429-76.

EATON, F. M.

1940. Interrelations in the effect of boron and indoleacetic acid on plant growth. Bot. Gaz. 101:700-5.

Eltinge, Ethel T.

1936. Effect of boron deficiency upon the structure of Zea Mays. Plant Physiol. 11:765-78.

HAAS, A. R. C.

1932. Some nutritional aspects in mottle-leaf and other physiological diseases of citrus. Hilgardia 6:483-559.

1945. Boron content in almond, olive and walnut trees. Amer. Soc. Hort. Sci. Proc. 46: 69-77. 1 fig.

HUMPHREY, H. B., and J. DUFRENOY.

1944. Host-parasite relationship between the oat plant (Avena spp.) and crown rust (Puccinia coronata). Phytopathology 34:21-40.

JoHNSTON, EARL S., and W. H. DoRe.

1929. The influence of boron on the chemical composition and growth of the tomato plant. Plant Physiol. 4:31-62.

KÜSTER, E.

1930. Anatomie der Gallen. Handb. Pflanzenanat. 5(1:3):1-197.

LöHNIS, MARIE P.

1940. Histology of boron deficiency in plants. Wageningen Landbouwhogesch. Meded. $44(3): 1-36$.

Mason, H. S., L. Schwartz, and Dorothy C. Peterson.

1945. The allergenic principles of poison ivy. $I V$. On the mechanism of the enzymatic oxidation of catechols. Jour. Amer. Chem. Soc. 67:1233.

Nelson, J. M., and C. R. DaWson.

1944. Tyrosinase. In: Advances in enzymology 4:100-52.

Purvis, E. R., and R. W. RuprechT.

1937. Cracked stem of celery caused by a boron deficiency in the soil. Florida Agr. Exp. Sta. Bul. 307:1-16.

REED, H. S.

1938. Cytology of leaves affected with little-leaf. Amer. Jour. Bot. 25:174-86.

1941. Effects of zine deficiency on cells of vegetative buds. Amer. Jour. Bot. 28:10-17

1944. The growth of ovules of Pisum in relation to zinc. Amer. Jour. Bot. 31:193-99.

REED, H. S., and J. DUFRÉNOY.

1935. The effects of zinc and iron salts on the cell structure of mottled orange leaves. Hilgardia 9 :113-41. 
Scott, C. E., H. Earl Thomas, and Harold E. Thomas.

1943. Boron deficiency in the olive. Phytopathology 33:933-42.

Scripture, P. N., and J. S. MCHARgue.

1945. Boron supply in relation to carbohydrate metabolism and distribution in the radish. Amer. Soc. Agron. Jour. $37: 360-64$.

VoGLER, K. G., and W. W. UMBreiT.

1942. Studies on the metabolism of the autotrophic bacteria. III. The nature of the energy storage material active in the chemosynthetic process. Jour. Gen. Physiol. 26:157-67.

WALKER, J. C.

1943. Histologic-pathologic effects of boron deficieney. Soil Sci. 57:51-54.

WARBURG, O., and W. Christian.

1943. Isolierung und Kristallization des Gärungsferments Zymohexase. Biochem. Zeitschr 314:149-76.

WARINGTON, Katherine.

1926. The changes induced in the anatomical structure of Vicia faba by the absence of boron from the nutrient solution. Ann. Bot. 40:27-42.

1940. The growth and anatomical structure of the carrot (Daucus carota) as affected by boron deficiency. Ann. Appl. Biol. 27:176-83.

WILLMER, E. N.

1942. The localization of phosphatase in cells in tissue cultures. Jour. Exp. Biol. 19:11-13. YIN, H. C.

1945. A histochemical study of the distribution of phosphatase in plant tissues. New Phytol. 44:191-95. 

- $5 x$

(1)

S.

(1)

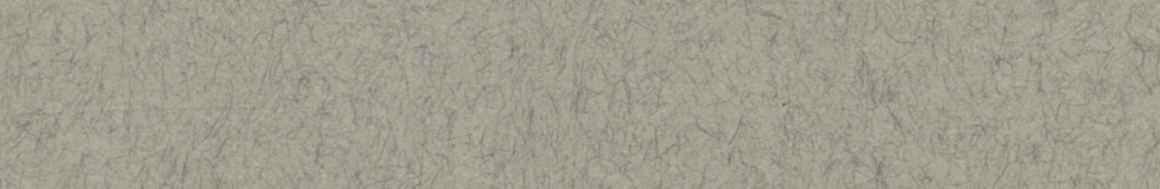

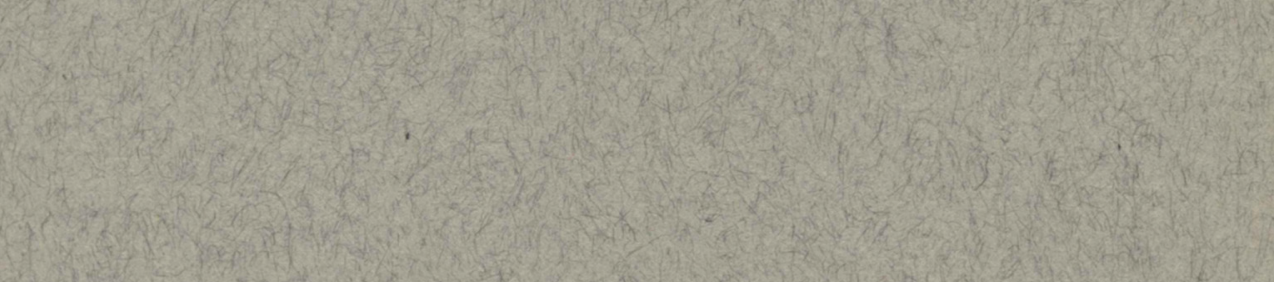

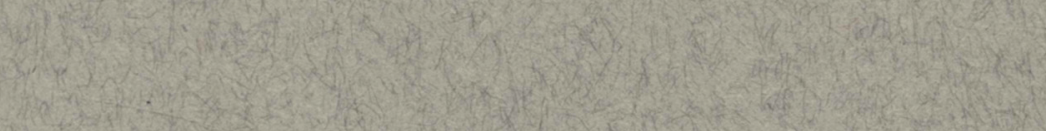

4.

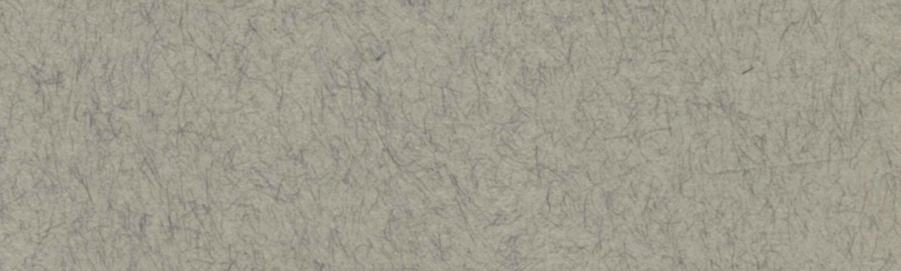

H.

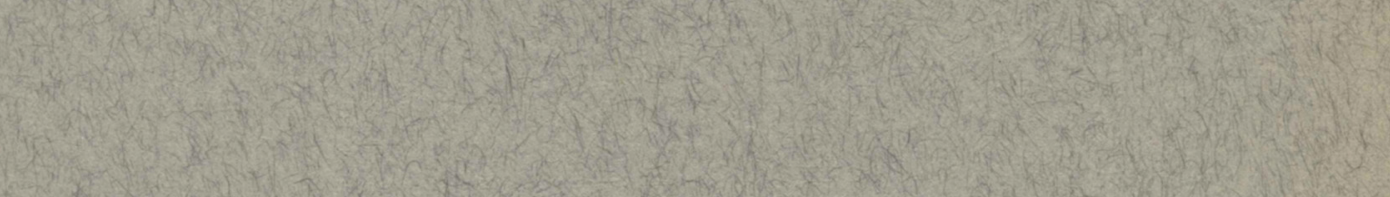

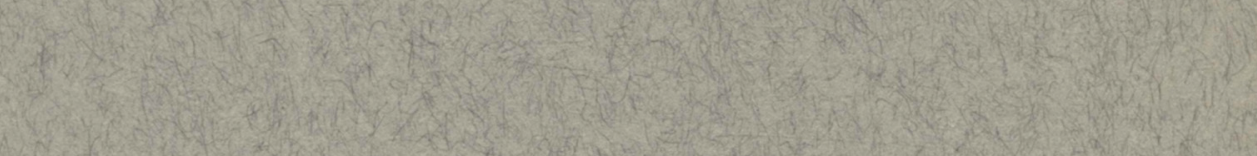

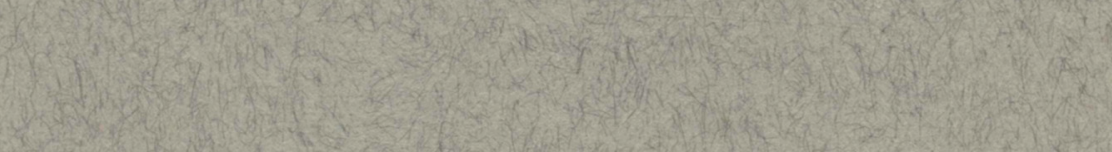

